\title{
Adsorption Behavior of Acid-Treated Brazilian Palygorskite for Cationic and Anionic Dyes Removal from the Water
}

\author{
Vanderlane C. Silva ${ }^{1}$ D, Maria Eduarda B. Araújo ${ }^{2}$, Alisson M. Rodrigues ${ }^{1,2, * \mathbb{D}}$, Juliana M. Cartaxo ${ }^{2}$, \\ Romualdo R. Menezes ${ }^{1,2}(\mathbb{D})$ and Gelmires A. Neves ${ }^{1,2}(D$ \\ 1 Graduate Program in Materials Science and Engineering (PPG-CEMat), Federal University of Campina \\ Grande, Campina Grande, PB 58429-900, Brazil; vanderlanecavalcanti@outlook.com (V.C.S.); \\ romualdo.menezes@ufcg.edu.br (R.R.M.); gelmires.neves@ufcg.edu.br (G.A.N.) \\ 2 Academic Unit of Materials Engineering, Science and Technology Center, Federal University of Campina \\ Grande, Campina Grande, PB 58429-900, Brazil; mariaeduardaba@hotmail.com (M.E.B.A.); \\ julianamelo25@gmail.com (J.M.C.) \\ * Correspondence: alisson.mendes@professor.ufcg.edu.br
}

Citation: Silva, V.C.; Araújo, M.E.B.; Rodrigues, A.M.; Cartaxo, J.M.;

Menezes, R.R.; Neves, G.A.

Adsorption Behavior of Acid-Treated Brazilian Palygorskite for Cationic and Anionic Dyes Removal from the Water. Sustainability 2021, 13, 3954. https://doi.org/10.3390/su13073954

Academic Editor: P. Senthil Kumar

Received: 11 February 2021

Accepted: 25 March 2021

Published: 2 April 2021

Publisher's Note: MDPI stays neutral with regard to jurisdictional claims in published maps and institutional affiliations.

Copyright: (c) 2021 by the authors. Licensee MDPI, Basel, Switzerland. This article is an open access article distributed under the terms and conditions of the Creative Commons Attribution (CC BY) license (https:// creativecommons.org/licenses/by/ $4.0 /)$.

\begin{abstract}
The effect of acid treatment on the adsorptive capacity of a Brazilian palygorskite to remove the crystal violet $(\mathrm{CV})$ and congo red $(\mathrm{CR})$ dyes was investigated. The raw palygorskite was acid-treated by different $\mathrm{HCl}$ solutions $(2,4$, and $6 \mathrm{~mol} / \mathrm{L})$. The modifications on the palygorskite structure were investigated using $\mathrm{X}$-ray diffraction, $\mathrm{X}$-ray fluorescence, Fourier-transform infrared spectroscopy, $\mathrm{N}_{2}$ adsorption/desorption, and thermogravimetric and differential thermal analysis. The efficiency of CV and CR adsorption was investigated, and the effect of the initial concentration, contact time, $\mathrm{pH}$, and adsorbent amount was analyzed. The results revealed that $\mathrm{CV}$ adsorption in the acid-treated palygorskite was higher than that of the raw material. A Langmuir isotherm model was observed for the adsorption behavior of $\mathrm{CV}$, while a Freundlich isotherm model was verified for the CR adsorption. A pseudo-second-order model was observed for the adsorption kinetics of both dyes. The higher $\mathrm{CV}$ adsorption capacity was observed at basic $\mathrm{pH}$, higher than $97 \%$, and the higher $\mathrm{CR}$ removal was observed at acidic $\mathrm{pH}$, higher than $50 \%$. The adsorption parameters of enthalpy $(\Delta \mathrm{H})$, entropy $(\Delta \mathrm{S})$, and Gibbs energy $(\Delta \mathrm{G})$ were evaluated. The adsorption process of the $C V$ and $\mathrm{CR}$ dyes on the raw and acid-treated Brazilian palygorskite was predominantly endothermic and occurred spontaneously. The studied raw palygorskite has a mild-adsorption capacity to remove anionic dyes, while acid-treated samples effectively remove cationic dyes.
\end{abstract}

Keywords: palygorskite; adsorption; anionic dye; cationic dye; water treatment

\section{Introduction}

The increase in industrial production and the world population has also increased water contamination from industrial and domestic sources [1]. Effluents derived from the textile, food, plastics, and cosmetics industries are rich in dyes [2,3]. Dyes have a complex structure, are stable to light and heat, can be highly toxic, potentially carcinogenic, and mutagenic [4], and rapidly accumulate in living cells and damage human health [5,6].

Crystal violet $(\mathrm{CV})$ is a cationic dye widely used in the textile, plastics, paint, and leather industries $[7,8]$. The $\mathrm{CV}$ dye is not biodegradable; it is toxic, genotoxic, and carcinogenic $[5,8,9]$. The presence of the crystal violet dye in water can promote the growth of tumors and reproductive abnormalities in fishes [10]. CV dye exposure can cause eye irritation and painful sensitization to light, and in extreme cases, respiratory diseases, kidney failure, chemical cystitis, permanent blindness, and cancer [7,11-13].

Congo red (CR) is an anionic dye often used in the textile, cellulose, rubber, and cosmetics industries [14,15]. In water, besides harming the photosynthesis of plants, the CR dye decomposes into carcinogenic and mutagenic substances [16,17]. In humans, the CR 
dye can cause skin and eye irritation, nausea, vomiting, and a high level of contaminationinduced respiratory diseases and cancer $[18,19]$.

Currently, the removal of dyes from water has become a huge challenge, and efficient and low-cost techniques have been sought with intensity in recent years [9]. Among the developments, nanofiltration [20], photocatalytic oxidation [21], coagulation/flocculation [22], electrochemistry [23], membrane filtration [24] and adsorption [25-27] stand out.

Adsorption presents great effectiveness, ease of operation, and low cost. Adsorbent material can be reused, applied to various pollutants, and be used in water treatment in a broad range of dye concentrations [28-30]. However, some adsorbent materials can present a high cost, especially notable in emerging countries, such as activated carbon [31,32]. This motivated the search for alternative low-cost and efficient adsorbents for the treatment of waters. Clays are often used as dye adsorbents due to their relatively low cost, abundance, availability, non-toxicity, and high adsorptive properties [32-36]. However, one of these clays, the palygorskite, has been studied less than others, despite its high potential for dye adsorption. In recent years, palygorskite has been investigated as an adsorbent for removing various contaminants because of its low cost and high surface area [32,36-40].

An Al-rich palygorskite with an $\mathrm{R}^{2+} / \mathrm{R}^{3+}$ ratio $\left(\mathrm{Mg}^{2+} /\left(\mathrm{Al}^{3+}+\mathrm{Fe}^{3+}\right)\right)$ of $\approx 0.26$ from Oman [41] was studied in relation to the removal of cationic/basic dyes, namely, methylene blue (MB) and crystal violet (CV), from aqueous solutions, and the adsorptive capacities of $50.8 \mathrm{mg} / \mathrm{g}$ and $57.8 \mathrm{mg} / \mathrm{g}$ for $\mathrm{MB}$ and $\mathrm{CV}$, respectively, were obtained. Three natural Mg-rich and Al-rich (Mg-poor) palygorskites from China [38] were studied to absorb cationic $\mathrm{MB}$ and the adsorptive capacities of $158.03 \mathrm{mg} / \mathrm{g}, 98.34 \mathrm{mg} / \mathrm{g}$, and $77.92 \mathrm{mg} / \mathrm{g}$ were obtained. The palygorskite with the lower $R^{2+} / R^{3+}(0.5)$ ratio and a dioctahedral character had the higher adsorption capacity [38]. However, studies [42] on Algerian palygorskite, with an $\mathrm{R}^{2+} / \mathrm{R}^{3+}$ ratio of $\approx 0.95$ and a dioctahedral-trioctahedral character, obtained an adsorptive capacity of just $15 \mathrm{mg} / \mathrm{g}$ for MB. These results indicate that the dioctahedral character, Al-rich palygorskite seems to favor the adsorption of cationic dyes.

An investigation that used a palygorskite from the Unites States with an $\mathrm{R}^{2+} / \mathrm{R}^{3+}$ of $\approx 0.95$ for the removal of reactive red 120 (anionic dye) [43] observed a low adsorptive capacity, not exceeding $0.5 \mathrm{mg} / \mathrm{g}$. A Brazilian palygorskite [44], with an $\mathrm{R}^{2+} / \mathrm{R}^{3+}$ of 0.75 and a dioctahedral-trioctahedral character, was used to remove remazol yellow (anionic dye) and obtained an adsorptive capacity of $20.08 \mathrm{mg} / \mathrm{g}$. These studies indicate that palygorskites with high $\mathrm{R}^{2+} / \mathrm{R}^{3+}$ present a low adsorption capacity for anionic dyes.

Yang et al. [33] investigated the adsorption capacity of the anionic and cationic dyes on the commercial Chinese palygorskite, which some metal ions $\left(\mathrm{Ca}^{2+}, \mathrm{Mg}^{2+}, \mathrm{Na}^{+}\right.$, and $\left.\mathrm{K}^{+}\right)$ were removed with the aid of soxhlet extraction. The metal ions removed implied more adsorption active sites for cationic dyes; thus, there was an improvement to the adsorption capacity for these dyes, such as the crystal violet and cationic light yellow dyes. On the other hand, before removing the metal ions, the commercial Chinese palygorskite showed a relatively high adsorptive capacity for anionic methyl orange dye. In this case, the metal ions act as bridges for efficient adsorption for these dyes. Other factors, such as the molecular structure of the dyes, were also identified as efficient in the adsorption. Another Chinese palygorskite was acid-treated with $\mathrm{HCl}$ [45] to be used in the adsorption of $\mathrm{MB}$, and a high adsorption capacity $(216.5 \mathrm{mg} / \mathrm{g})$ was achieved. These studies indicate that acid treatment improves adsorption capacity for cationic and anionic dyes in palygorskites with a dioctahedral-trioctahedral character.

These studies indicate a high potential for water treatment with palygorskites. It was observed that the adsorptive potential of Chinese palygorskites has been well discussed in the literature. In contrast, few studies have approached the adsorptive potential of the Brazilian palygorskite for dye removal [44,46]. Furthermore, little has been explored about how acid treatment affects the Brazilian palygorskite structure [47]. Thus, this work aimed to analyze the effect of acid treatment on Brazilian palygorskite structure and to evaluate its potential in treating water contaminated with dyes. 


\section{Materials and Methods}

\subsection{Raw Materials}

Palygorskite clay investigated in this work it is from Guadalupe City, Piauí State, Brazil, and was supplied by União Brasileira de Mineração S.A. (UBM). The crystal violet dye (CV) (Synth, Brazil), congo red dye (CR) (Dinâmica Química, Brazil), hydrochloric acid, and ammonium hydroxide (VETEC, Brazil) were the other raw materials used in this study.

\subsection{Acid Treatment}

The as-received palygorskite was treated at $60{ }^{\circ} \mathrm{C}$ for $24 \mathrm{~h}$, sieved $(0.074 \mathrm{~mm})$, and acidtreated with $\mathrm{HCl}$. Then, $50 \mathrm{~g}$ of palygorskite was immersed in $500 \mathrm{~mL}$ of hydrochloric acid solution in different concentrations $(2,4$, and $6 \mathrm{~mol} / \mathrm{L})$ under reflux conditions for $2 \mathrm{~h}$ at $70{ }^{\circ} \mathrm{C}$. The mixture was filtered under vacuum and washed several times with distilled water until the filtered solution reached a $\mathrm{pH}=7$. Finally, the material obtained was dried for $12 \mathrm{~h}$ at $60^{\circ} \mathrm{C}$. Table 1 shows the nomenclatures used for the raw and activated palygorskite.

Table 1. Nomenclature of the samples with and without acid treatment.

\begin{tabular}{ccc}
\hline Treatment & Acid Concentration & Sample Nomenclature \\
\hline None & - & Pal \\
Acid & $\mathrm{HCl}-2 \mathrm{~mol} / \mathrm{L}$ & Pal-2M \\
Acid & $\mathrm{HCl}-4 \mathrm{~mol} / \mathrm{L}$ & Pal-4M \\
Acid & $\mathrm{HCl}-6 \mathrm{~mol} / \mathrm{L}$ & $\mathrm{Pal}-6 \mathrm{M}$ \\
\hline
\end{tabular}

\subsection{Characterizations}

X-ray diffraction (Shimadzu, XRD-6000) was performed using $\mathrm{CuK} \alpha(\lambda=1.54 \AA)$, operated at $40 \mathrm{kV}$ and $30 \mathrm{~mA}$, in a $2 \theta$ angular range of $5^{\circ}-50^{\circ}$ and $0.02^{\circ}$ of step size [46,47]. The chemical analysis was determined using an X-ray fluorescence spectrometry (Shimadzu, EDX-720). Infrared spectra with Fourier-transform infrared spectrometry (FTIR) were recorded in the spectral range from $4000 \mathrm{~cm}^{-1}$ to $400 \mathrm{~cm}^{-1}$, with 32 scans and $4 \mathrm{~cm}^{-1}$ resolution, using KBr pellets (Bruker, Vertex-70). Thermogravimetric (TG) and differential thermal analysis (DTA) were performed under an air atmosphere, with a heating rate of $10^{\circ} \mathrm{C} / \mathrm{min}$ (Shimadzu, DTG-60H). A nitrogen adsorption/desorption test (Quantachrome, Autosorb iQ) was performed and the specific surface area and pore diameter were determined using the Brunauer-Emmett-Teller (BET) method $[48,49]$.

\subsection{Adsorption Experiments}

Adsorption tests were performed to investigate the effect of contact time, initial adsorbate concentration, adsorbent dosage, and $\mathrm{pH}$ variation. The adsorbent-solution systems were shaking $(150 \mathrm{rpm})$ at $25^{\circ} \mathrm{C}$ for up $360 \mathrm{~min}$. After shaking, the samples were centrifuged at $3600 \mathrm{rpm}$ for $5 \mathrm{~min}$. The residual dye concentrations in the supernatant were measured by absorbance at $582.5 \mathrm{~nm}$ and $501 \mathrm{~nm}$ for $\lambda_{\max }$ for the CV and CR dyes, respectively. The experiments were accomplished by UV-vis absorption spectrophotometry (UV-1800, Shimadzu). The amount of CV and CR dyes adsorbed on the Pal, Pal-2M, Pal-4M, and Pal-6M samples was calculated using Equation (1) [50], and the removal percentage was calculated using Equation (2) [51]:

$$
\begin{gathered}
\mathrm{q}_{e}=\left[\left(\mathrm{C}_{o}-\mathrm{C}_{e}\right) \mathrm{V}\right] / \mathrm{m} \\
\text { \%adsorbed }=\left[\left(\mathrm{C}_{o}-\mathrm{C}_{e}\right) / \mathrm{C}_{o}\right] \times 100
\end{gathered}
$$

where $\mathrm{q}_{e}(\mathrm{mg} / \mathrm{g})$ is the adsorption capacity, $\mathrm{C}_{o}(\mathrm{mg} / \mathrm{L})$ and $\mathrm{C}_{e}(\mathrm{mg} / \mathrm{L})$ are the initial and equilibrium concentrations, respectively, $\mathrm{V}(\mathrm{L})$ is the volume of the solution, and $\mathrm{m}(\mathrm{g})$ is the mass of the palygorskite samples. 
To study the effect of the CV and CR dye concentrations, $20 \mathrm{mg}$ of the investigated samples were added in flasks containing $20 \mathrm{~mL}$ of the dye solution with different concentrations ranging from 2.5 to $200 \mathrm{mg} / \mathrm{L}$. The $\mathrm{pH}$ of 7 was kept constant. The effects of contact time (15-360 $\mathrm{min}), \mathrm{pH}(3,5,7,9$, and 11$)$, and temperature $\left(25-55^{\circ} \mathrm{C}\right)$ were investigated by adding $20 \mathrm{mg}$ of the investigated samples (Pal, Pal-2M, Pal-4M, and Pal-6M) into $20 \mathrm{~mL}$ of the $\mathrm{CV}$ or $\mathrm{CR}$ solution with a $50 \mathrm{mg} / \mathrm{L}$ concentration. The initial $\mathrm{pH}$ of the solutions was adjusted by adding $0.1 \mathrm{M} \mathrm{NH}_{4} \mathrm{OH}$ or $\mathrm{HCl}$. The influence of the adsorbent dosage was analyzed by varying the amount of samples between 10 to $40 \mathrm{mg}$ at a concentration of CV and $\mathrm{CR}$ of $50 \mathrm{mg} / \mathrm{L}$ at $\mathrm{pH}=7$.

\subsection{Isothermal, Kinetic, and Thermodynamic Studies}

The Langmuir (Equation (3)) [52] and Freundlich (Equation (4)) [53,54] isothermal models were used in the analysis of adsorption data:

$$
\mathrm{C}_{e} / \mathrm{q}_{e}=\left[1 /\left(\mathrm{q}_{\max } \cdot \mathrm{K}_{L}\right)\right]+\left(\mathrm{C}_{e} / \mathrm{q}_{\max }\right)
$$

where $\mathrm{q}_{e}(\mathrm{mg} / \mathrm{g})$ is the amount adsorbed in the equilibrium, $\mathrm{C}_{e}(\mathrm{mg} / \mathrm{L})$ is the equilibrium concentration, $\mathrm{q}_{\max }(\mathrm{mg} / \mathrm{g})$ represents the maximum adsorption, and $\mathrm{K}_{\mathrm{L}}(\mathrm{L} / \mathrm{mg})$ is the Langmuir constant.

$$
\log \mathrm{q}_{e}=\log \mathrm{K}_{f}+1 / \mathrm{n}\left(\log \mathrm{C}_{e}\right)
$$

where $\mathrm{C}_{e}$ and $\mathrm{q}_{e}$ are as defined above, and $\mathrm{K}_{f}\left((\mathrm{mg} / \mathrm{g})(\mathrm{L} / \mathrm{mg})^{1 / \mathrm{n}}\right)$ and $1 / \mathrm{n}$ are the Freundlich constants characteristic of the system. $\mathrm{K}_{f}$ represents an approximate value of the adsorption capacity, and $1 / \mathrm{n}$ indicates the intensity of the adsorption process and is related to the heterogeneity of the surface, with values between 0 and 1 ; the closer the value is to 0 , the more heterogeneous the surface.

To examine the adsorption kinetics, the pseudo-first-order (Equation (5)) [55] and pseudo-second-order (Equation (6)) [56] models were used:

$$
\ln \left(\mathrm{q}_{e}-\mathrm{q}_{t}\right)=\ln \mathrm{q}_{e}-\mathrm{k}_{1} \mathrm{t}
$$

where $\mathrm{q}_{e}$ is as defined above, $\mathrm{q}_{t}(\mathrm{mg} / \mathrm{g})$ is the amount of adsorbate adsorbed at a given time, $\mathrm{k}_{1}\left(\mathrm{~min}^{-1}\right)$ is the pseudo-first-order speed constant, and $t$ is the contact time in minutes (min).

$$
\mathrm{t} / \mathrm{q}_{t}=1 /\left(\mathrm{k}_{2} \mathrm{q}_{e}{ }^{2}\right)+\mathrm{t} / \mathrm{q}_{e}
$$

where $\mathrm{q}_{e}$ and $\mathrm{q}_{t}$ are the same as defined above, $\mathrm{k}_{2}\left(\mathrm{~g} \cdot \mathrm{mg}^{-1} \cdot \mathrm{min}^{-1}\right)$ is the pseudo-secondorder speed constant, and $t$ is the contact time in minutes ( $\mathrm{min}$ ).

The thermodynamic parameters were determined from the experimental data using the Van't Hoff equations (Equations (7)-(9)) [42,57]:

$$
\begin{gathered}
\operatorname{Ln} \mathrm{K}_{\mathrm{d}}=(\Delta \mathrm{S} / \mathrm{R})-(\Delta \mathrm{H} / \mathrm{RT}) \\
\Delta \mathrm{G}=-\mathrm{RTLn} \mathrm{K}_{\mathrm{d}} \\
\mathrm{K}_{\mathrm{d}}=\mathrm{q}_{e} / \mathrm{C}_{e}
\end{gathered}
$$

where $\mathrm{R}(8.314 \mathrm{~J} / \mathrm{mol} \mathrm{K})$ is the universal gas constant, $\mathrm{T}(\mathrm{K})$ is the studied temperature, $\mathrm{K}_{\mathrm{d}}$ is the distribution coefficient for adsorption, and $\Delta \mathrm{H}, \Delta \mathrm{S}$, and $\Delta \mathrm{G}$ are the variations of enthalpy, entropy, and Gibbs energy, respectively.

\subsection{Regeneration of Adsorbents}

The adsorbents loaded with $\mathrm{CV}$ and $\mathrm{CR}$ were desorbed using $40 \mathrm{~mL}$ of $1 \mathrm{M} \mathrm{CH}_{3} \mathrm{COOH}$ solution and stirred in a shaker at $120 \mathrm{rpm}$ for $8 \mathrm{~h}$. Then, the adsorbents were washed with distilled water and placed in the oven at $60^{\circ} \mathrm{C}$ for $12 \mathrm{~h}$. After drying, they were reused for 4 cycles. 


\section{Results and Discussion}

\subsection{Characterization of Raw and Acid-Treated Palygorskite}

X-ray diffraction (XRD) patterns of the raw and acid-treated $(2,4$, and $6 \mathrm{~mol} / \mathrm{L})$ Brazilian palygorskite are illustrated in Figure 1. Palygorskite (ICCD 21-0958) and quartz (ICCD 46-1045) phases were identified in the raw and acid-activated clays, as observed in other studies [58-60]. Câmara et al. and Suarez et al. $[39,58]$ reported that the palygorskite can be classified into three types: Type I has similar $\mathrm{Al}$ and $\mathrm{Mg}$ contents and negligible isomorphic substitutions $\left(\mathrm{d}_{200}<6.35 \AA\right)$; Type II is rich in Al contents and has a dioctahedral character, and this is the most commonly found type $\left(6.35<\mathrm{d}_{200}<6.46 \AA\right)$; and Type III is rich in $\mathrm{Mg}$ contents and has a trioctahedral character $\left(\mathrm{d}_{200}>6.46 \AA\right)$. The Brazilian palygorskite investigated in this work has a $d_{200}$ equal to $6.39 \AA$; therefore, it belongs to Type II.

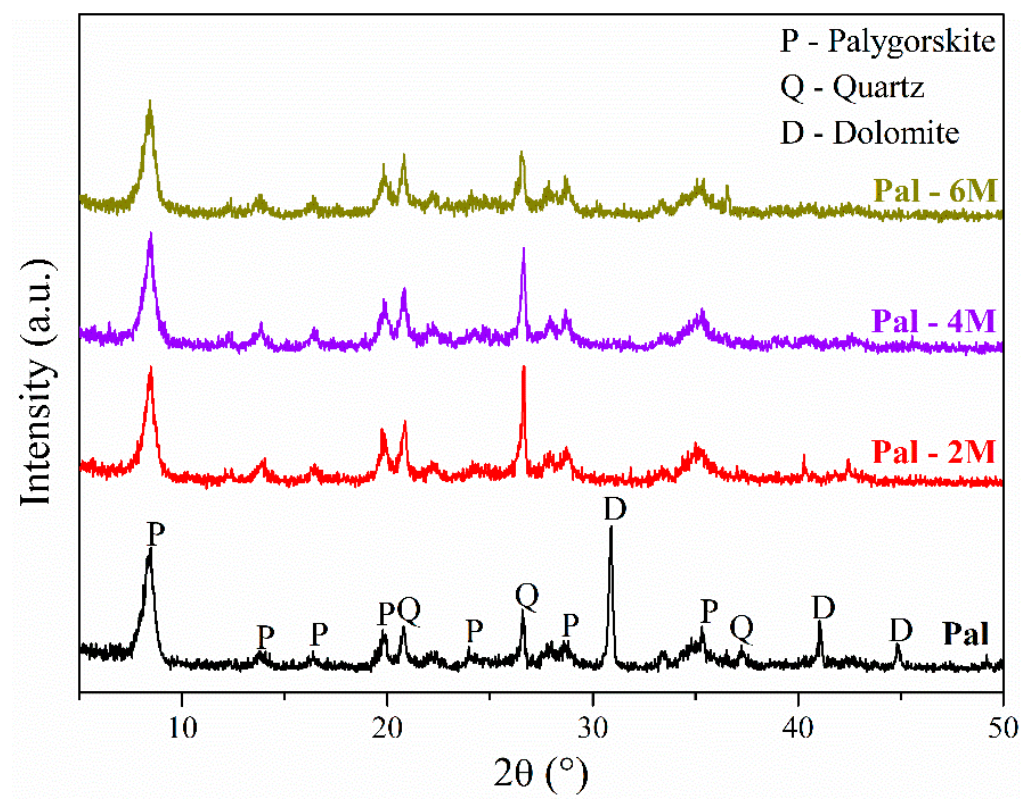

Figure 1. X-ray diffraction (XRD) pattern of raw palygorskite and acid-treated palygorskite.

The XRD patterns indicated that the structure of the Brazilian palygorskite was not significantly altered by the acid treatment. Quartz reflections remained stable due to their insolubility in acidic solution [61-63]. Studies depicted the formation of amorphous $\mathrm{SiO}_{2}$ because of the acid treatment $[61,63,64]$; however, no amorphous band $[65,66]$ was identified in the range of $2 \theta$ between 20 and $35^{\circ}$ in the acid-treated Brazilian palygorskite. The absence of an amorphous band can be attributed to the short acid-treatment time, which was inefficient in destroying the tetrahedral crystalline sheet of palygorskite. On the other hand, the reflections corresponding to dolomite (ICCD 36-0426) were not identified in the XRD standards of the acid-treated samples, indicating the dissolution of this carbonate with the acid treatment observed in other studies [64].

The chemical analysis (Table 2) showed that the palygorskite samples investigated were mostly composed of $\mathrm{SiO}_{2}, \mathrm{MgO}$, and $\mathrm{Al}_{2} \mathrm{O}_{3}$, which indicates the presence of hydrated magnesium and aluminum silicate on this palygorskite mineral [61]. The raw palygorskite had an $\mathrm{R}^{2+} / \mathrm{R}^{3+}$ ratio $\approx 1$, but the acid-treated samples had an $\mathrm{R}^{2+} / \mathrm{R}^{3+}$ ratio $\approx 0.6$. The $\mathrm{R}^{2+} / \mathrm{R}^{3+}$ ratio $\approx 1$ is related to the high amount of $\mathrm{MgO}$ in the sample due to dolomite presence. After acid-treatment, dolomite was removed; thus, the more confident $R^{2+} / R^{3+}$ ratio $\approx 0.6$ was obtained. This 0.6 ratio indicates that the studied sample had an intermediate dioctahedral and trioctahedral character, such as the other Brazilian palygorskite already studied [44]. Palygorskite with such characteristics [44] presented a low adsorption capacity for anionic dye. 
Table 2. Chemical composition ( $(\mathrm{w} t \%)$ of raw and acid-treated palygorskite.

\begin{tabular}{cccccccc}
\hline Sample & $\mathbf{S i O}_{2}$ & $\mathbf{M g O}$ & $\mathbf{A l}_{\mathbf{2}} \mathbf{O}_{\mathbf{3}}$ & $\mathbf{C a O}$ & $\mathbf{F e}_{\mathbf{2}} \mathbf{O}_{\mathbf{3}}$ & $\mathbf{K}_{\mathbf{2}} \mathbf{O}$ & $\begin{array}{c}\text { Other } \\
\text { Oxides }\end{array}$ \\
\hline Pal & 52.8 & 13.9 & 13.5 & 11.9 & 5.3 & 0.9 & 1.7 \\
Pal-2M & 69.3 & 8.3 & 13.5 & 0 & 5.2 & 0.9 & 2.8 \\
Pal-4M & 71.9 & 7.6 & 13.4 & 0 & 4.5 & 0.8 & 1.8 \\
Pal-6M & 73.4 & 7.1 & 13.4 & 0 & 4.0 & 0.8 & 1.2 \\
\hline
\end{tabular}

The acid-treated samples (Pal-2M, Pal-4M, and Pal-6M) presented a progressive decrease in the $\mathrm{MgO}, \mathrm{Al}_{2} \mathrm{O}_{3}$, and $\mathrm{Fe}_{2} \mathrm{O}_{3}$ contents (octahedral cations) with the rise in $\mathrm{HCl}$ concentration. The decrease in the $\mathrm{MgO}, \mathrm{Al}_{2} \mathrm{O}_{3}$, and $\mathrm{Fe}_{2} \mathrm{O}_{3}$ contents indicates that there was leaching of $\mathrm{Mg}^{2+}, \mathrm{Al}^{3+}$, and $\mathrm{Fe}^{3+}$ ions in the treated samples because of the dissolution of dolomite (contain $\mathrm{MgO}$ ) [67] and the removal of ions of the octahedral sheet.

The extent of the leaching of $\mathrm{Mg}^{2+}$ and $\mathrm{Fe}^{3+}$ ions was higher than that of $\mathrm{Al}^{3+}$ ions. According to the literature $[32,62,68]$, the $\mathrm{Mg}^{2+}$ and $\mathrm{Fe}^{3+}$ cations are preferably located on the edges of the octahedral sheets. Therefore, the $\mathrm{Mg}^{2+}$ and $\mathrm{Fe}^{3+}$ cations are the first ones attacked by the $\mathrm{H}^{+}$protons, which results in the most significant leaching $[32,62,68]$. The higher leaching of octahedral sheet cations resulted in a more exposed silica sheet after acid-treatment $[63,64]$, which can influence the adsorption behavior of the final material.

After acid-treatment, the $\mathrm{CaO}$ content was reduced to zero, since the dolomite was dissolved in an acidic medium [67], corroborating the XRD results. The decrease in $\mathrm{K}_{2} \mathrm{O}$ content is due to the exchangeable cations being replaced by $\mathrm{H}^{+}$ions during the acid treatment $[69,70]$.

The FTIR spectra data measured from the raw and acid-treatment Brazilian palygorskite are shown in Figure 2. From the raw palygorskite, the observed $3612 \mathrm{~cm}^{-1}$ band can be attributed to the $\mathrm{Al}-\mathrm{OH}-\mathrm{Al}$ stretching vibration and the $3578 \mathrm{~cm}^{-1}$ band was associated with the Al-Fe ${ }^{3+}-\mathrm{OH}$ or $\mathrm{Al}-\mathrm{Mg}-\mathrm{OH}$ stretching vibrations [64,71-73]. The 3541, 3374, 3268 , and $1656 \mathrm{~cm}^{-1}$ bands were also detected and related to the zeolitic and coordinate waters present in the palygorskite structure [42,74]. The calcite was related to bands that appeared in 1439 and $729 \mathrm{~cm}^{-1}[75,76]$, and it became evident that there were carbonate impurities in the studied sample. The bands between 1190 and $975 \mathrm{~cm}^{-1}$ corresponded to Si-O bond length. The 1190 and $642 \mathrm{~cm}^{-1}$ bands were considered palygorskite fingerprints and referred to the asymmetric and symmetrical elongation of the Si-O-Si connections $[77,78]$. The $909 \mathrm{~cm}^{-1}$ band can be attributed to the Al-OH-Al deformation and was considered a consequence of the palygorskite's dioctahedral character [38,76]. The $877 \mathrm{~cm}^{-1}$ band was related to the flexion vibration mode of the Al-Fe-OH bond [38]. The $580 \mathrm{~cm}^{-1}$ band corresponded to the Si-O deformation vibration $[77,79]$.

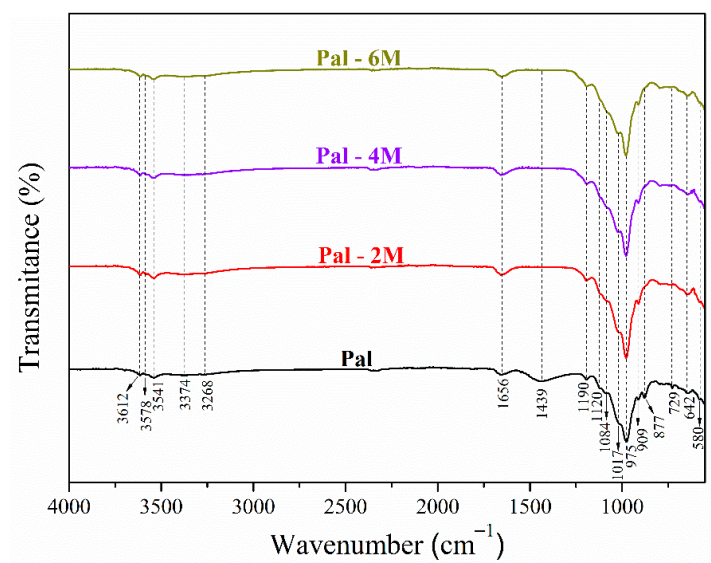

Figure 2. Fourier-transform infrared spectrometry (FTIR) spectra of the raw and acid-treated palygorskite. 
In Figure 2, it was observed that after acid-treatment, the bands referring to calcite (1439 and $729 \mathrm{~cm}^{-1}$ ) and the $877 \mathrm{~cm}^{-1}$ band disappeared, while the intensities of the 1190 and $975 \mathrm{~cm}^{-1}$ bands increased. This was related to dolomite dissolution and Fe leaching from the octahedral sheet. Octahedral cations are generally more susceptible to leaching than the tetrahedral Si $[80,81]$, which favors the intensity of Si-related bands.

Some mass-loss events were identified on TG analysis (Figure 3). The first event between $23-125^{\circ} \mathrm{C}$ was related to the evaporation of water that was physically adsorbed [82], and the values measured were equal to $6.5 \%, 9.4 \%, 8.4 \%$, and 9.5\% for the Pal, Pal-2M, Pal$4 \mathrm{M}$, and Pal-6M samples, respectively. The second event $\left(125-230{ }^{\circ} \mathrm{C}\right)$ corresponded to the coordinated and zeolitic water molecules located in the palygorskite's channels [83]. The percentages of mass loss measured for the second event were $2.3 \%, 3.4 \%, 2.5 \%$, and $2.4 \%$ for the Pal, Pal-2M, Pal-4M, and Pal-6M samples, respectively. The third event occurred between $230-530{ }^{\circ} \mathrm{C}$ and presented a mass loss equal to $4.9 \%, 5.3 \%, 5.4 \%$, and $5.1 \%$ to the Pal, Pal-2M, Pal-4M, and Pal-6M samples, respectively. These mass losses can be attributed to the dehydroxylation process and condensation of silanol and aluminol groups $[39,84]$. Only the Pal sample showed a mass loss $(12.6 \%)$ between $530-720{ }^{\circ} \mathrm{C}$. This thermal event is related to dolomite decomposition [85]. The dolomite composition agreed with the aforementioned chemical analysis, which showed that the acid-treatment released $\mathrm{CaO}$ contents from the Brazilian palygorskite. The DTA curves presented endothermic peaks in the same temperature range of the losses of mass observed in the TG curves. The DTA peaks were attributed to the evaporation of physically adsorbed water molecules [86], the release of zeolitic water molecules [87], the removal of coordinated water, the condensation of surface groups [88], and the dolomite decomposition [89].
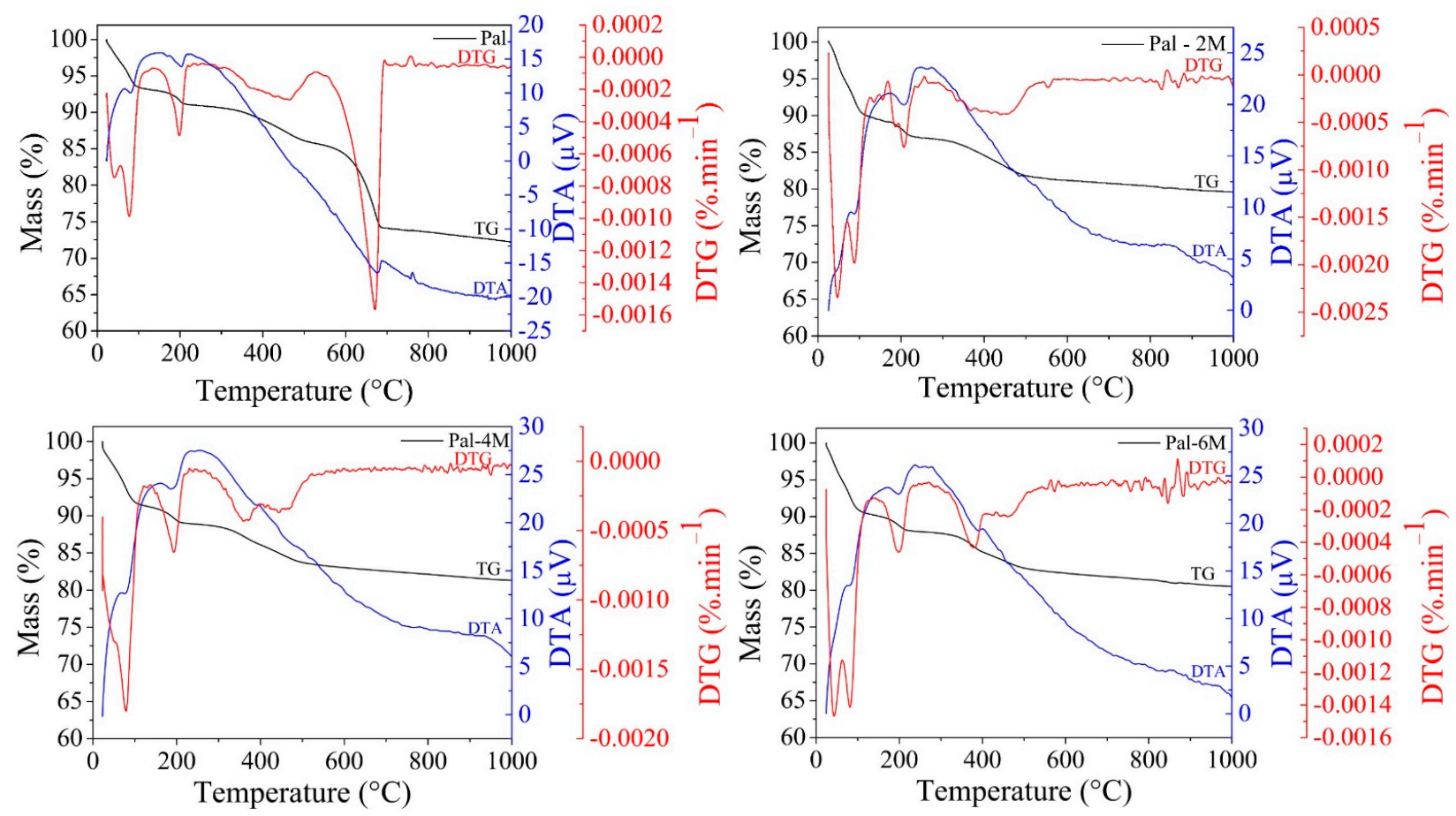

Figure 3. Thermogravimetric (TG) and differential thermal analysis (DTA) curves of the raw and acid-treated palygorskite.

The acid-treated samples presented endothermic peaks similar to those observed in the raw palygorskite, except the peak related to the loss of mass of the dolomite decomposition, which was not observed in the acid-treated samples because of the removal of this impurity. The $4 \mathrm{M}$ and $6 \mathrm{M}$ acid-treated samples also presented a different loss of mass behavior between $350{ }^{\circ} \mathrm{C}$ and $500{ }^{\circ} \mathrm{C}$, with two peaks in TG instead of a broad band of mass loss, as was observed in the raw and the $2 \mathrm{M}$ acid-treated sample. This can be related to alterations in the dehydroxylation kinetic process. 
The specific surface area $\left(\mathrm{S}_{\mathrm{BET}}\right)$ and average pore diameter $\left(\mathrm{D}_{\mathrm{p}}\right)$ of the raw and acidtreated Brazilian palygorskite are listed in Table 3. After acid-treatment, the increase in $\mathrm{S}_{\mathrm{BET}}$ can be explained because of the removal of carbonate impurities, leaching of cations from the octahedral sheet, and disaggregation of particles [80,90]. However, when the acid concentration increased from $4 \mathrm{M}$ to $6 \mathrm{M}$, a small $\mathrm{S}_{\mathrm{BET}}$ reduction was observed. This behavior can be related to a more pronounced collapse of the palygorskite channels [32,64]. Also, a decrease in $\mathrm{D}_{\mathrm{p}}$ values was observed for the Pal-4M and Pal-6M samples, possibly because, in high $\mathrm{HCl}$ concentrations, there is a partial collapse of the channels and a decrease in pore size. However, Gonzalez et al. [91] reported developing a new pore system with a smaller pore size in acid-treated palygorskite. This indicates that with the rise in acid concentration, there is an increase in surface area due to a leaching of octahedral sheets and the exposition of new reactive sites. At high acid concentration, the channels begin to collapse, decreasing the average pore size.

Table 3. Specific surface area $\left(\mathrm{S}_{\mathrm{BET}}\right)$ and average pore diameter $\left(\mathrm{D}_{\mathrm{p}}\right)$ of the raw and acidtreated palygorskite.

\begin{tabular}{ccc}
\hline Sample & Specific Surface Area $\left(\mathbf{m}^{2} / \mathbf{g}\right)$ & Average Pore Diameter $(\mathbf{n m})$ \\
\hline Pal & 80.4 & 14.3 \\
Pal-2M & 141.2 & 15.2 \\
Pal-4M & 182.2 & 13.0 \\
Pal-6M & 176.9 & 13.3 \\
\hline
\end{tabular}

\subsection{Optimization of Adsorption Conditions}

\subsubsection{Effect of Dye Concentrations}

The effect of the initial concentration of crystal violet $\left(\mathrm{C}_{i}{ }^{\mathrm{CV}}\right)$ and congo red $\left(\mathrm{C}_{i}{ }^{\mathrm{CR}}\right)$ dyes on the adsorption capacity of raw and acid-treated Brazilian palygorskite is shown in Figure 4a,b. Different CV and CR concentrations ( 2.5 to $200 \mathrm{mg} / \mathrm{L}$ ) were tested for a contact time equal to $360 \mathrm{~min}, \mathrm{pH} \mathrm{7}$, and clay samples with a weight of $20 \mathrm{mg}$. It was observed that the adsorbed amount $\left(\mathrm{q}_{e}\right)$ raised significantly as $\mathrm{C}_{i}{ }^{\mathrm{CV}}$ and $\mathrm{C}_{i}{ }^{\mathrm{CR}}$ increased. This behavior is explained in terms of the greater probability of collision between the dye molecules and the palygorskite surface. Besides, the increases in $\mathrm{C}_{i}{ }^{\mathrm{CV}}$ and $\mathrm{C}_{i}{ }^{\mathrm{CR}}$ contribute to increasing the driving force at the solid-liquid interface that exceeds the mass transfer resistance, implying an increase in the adsorption capacity [28].
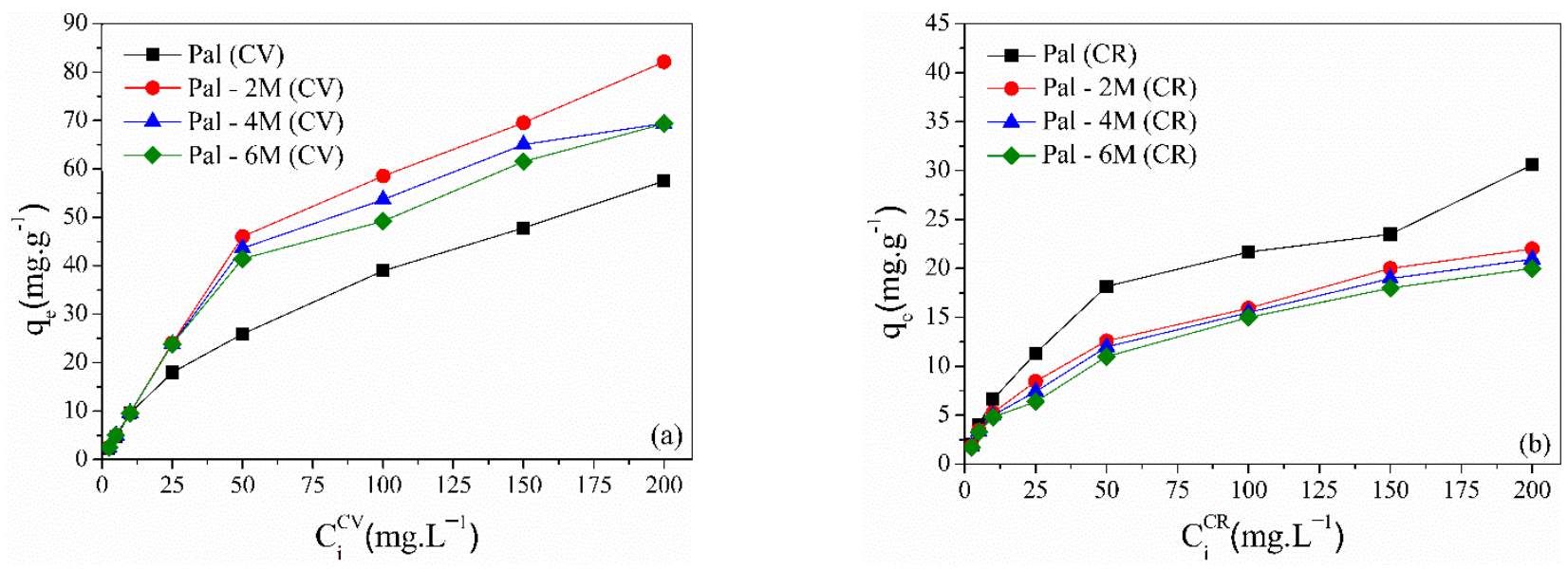

Figure 4. Effect of initial concentration on the adsorption capacity of raw and acid-treated palygorskite for (a) CV and (b) CR.

On the raw Brazilian palygorskite, the adsorption capacity values of the $\mathrm{CV}$ dye were higher than those measured for the CR dye. Such behavior can be explained in terms of the electrostatic attraction, since that raw palygorskite contains negative charges in its 
surface [30,33]. The maximum CV adsorption capacity was: Pal-2M $(82.1 \mathrm{mg} / \mathrm{g})>\mathrm{Pal}-4 \mathrm{M}$ $(69.4 \mathrm{mg} / \mathrm{g})>\mathrm{Pal}-6 \mathrm{M}(69.3 \mathrm{mg} / \mathrm{g})>\mathrm{Pal}(57.5 \mathrm{mg} / \mathrm{g})$. Compared to the raw palygorskite, the amount adsorbed increased by $43 \%, 21 \%$, and $20.5 \%$ for the Pal-2M, Pal- $4 \mathrm{M}$, and Pal- $6 \mathrm{M}$ samples, respectively. This indicates that the adsorption performance of palygorskite for $\mathrm{CV}$ was improved with the acid-treatment. The amount adsorbed by raw clay was similar to the amount adsorbed by clay with $\mathrm{R}^{2+} / \mathrm{R}^{3+} \approx 0.26$ [41], with a dioctahedral character. This indicates that clays with dioctahedral and dioctahedral-trioctahedral characters (as in the case of this work) have a similar CV adsorption capacity.

The maximum CR adsorption capacity was: Pal $(30.6 \mathrm{mg} / \mathrm{g})>\mathrm{Pal}-2 \mathrm{M}(22 \mathrm{mg} / \mathrm{g})>$ Pal-4M $(20.9 \mathrm{mg} / \mathrm{g}) \approx \mathrm{Pal}-6 \mathrm{M}(20 \mathrm{mg} / \mathrm{g})$. The lower adsorption capacity of the palygorskite to the $\mathrm{CR}$ was attributed to the electrostatic repulsion between the negatively charged surface and the negative nature of the CR dye [92]. Furthermore, Yang et al. [33] pointed out that the leaching of $\mathrm{Mg}^{2+}$ and $\mathrm{Ca}^{2+}$ ions decreases the zeta potential of palygorskite clay and reduces the anionic dyes' absorptive capacity. This behavior can be explained in terms of the exposition of silica negatively charged sites, which improved the adsorption of the cationic $\mathrm{CV}$ dye, but reduced the $\mathrm{CR}$ adsorption capacity after acid treatment.

\subsubsection{Effect of Contact Time}

Figure $5 \mathrm{a}, \mathrm{b}$ shows the amount of $\mathrm{CV}$ and $\mathrm{CR}$ adsorbed on the raw and acid-treated samples as a function of contact time. CV and CR solutions with initial concentrations of $50 \mathrm{mg} / \mathrm{L}$, for a constant $20 \mathrm{mg}$ clay sample mass and $\mathrm{pH} 7$ were used to study the adsorption kinetics. Initially, the $\mathrm{CV}$ adsorption was fast for all samples, achieving about $40 \%$ of adsorption in the first $30 \mathrm{~min}$. This is due to the numerous active sites available on the surface of the adsorbent in the early stages [45] and the strong electrostatic interaction between the negatively charged palygorskite surface and the cationic CV [41]. When equilibrium was reached in $240 \mathrm{~min}$, the adsorption capacity and CV removal values were $26.02 \mathrm{mg} / \mathrm{g}$ and $52 \%$, respectively. The Pal-2M, Pal-4M, and Pal-6M samples removed approximately $92 \%(45.95 \mathrm{mg} / \mathrm{g}), 84 \%(42.1 \mathrm{mg} / \mathrm{g})$, and $80 \%(40.38 \mathrm{mg} / \mathrm{g})$ of the CV, respectively. For the CR dye, the adsorption kinetics was slower, and in $30 \mathrm{~min}$, less than $18 \%$ of the dye was removed. The equilibrium was achieved in $240 \mathrm{~min}$ with the removal of $36.34 \%$ (18.17 mg/g), $25.12 \%$ (12.56 mg/g), 23.98\% (11.99 mg/g), and $22 \%(11 \mathrm{mg} / \mathrm{g})$ of the CR dye for the Pal, Pal-2M, Pal-4M, and Pal-6M samples, respectively.
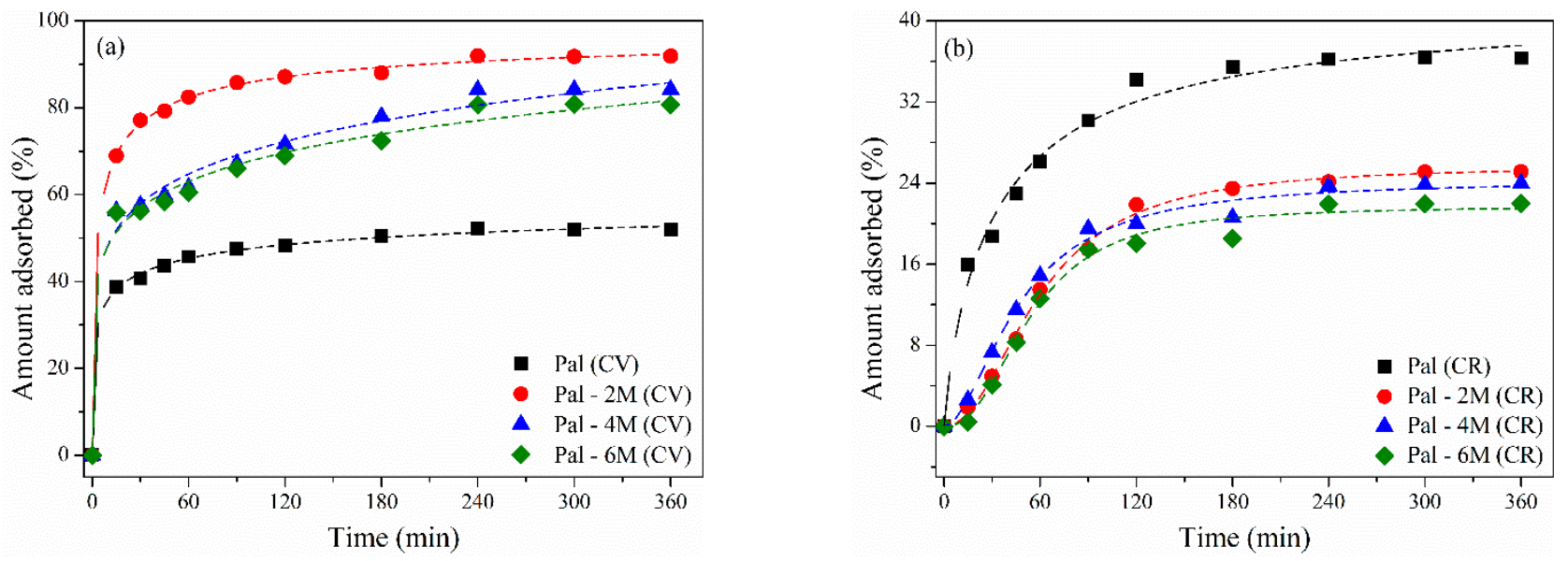

Figure 5. Effect of contact time on (a) crystal violet (CV) adsorption and (b) congo red (CR) adsorption on palygorskite before and after acid treatment.

\subsubsection{Effect of $\mathrm{pH}$ Variation}

Figure $6 \mathrm{a}, \mathrm{b}$ shows the effects of $\mathrm{pH}$ on the adsorption of $\mathrm{CV}$ and $\mathrm{CR}$ in the palygorskite before and after acid treatment. The experiments were performed using $50 \mathrm{mg} / \mathrm{L}$ of the 
initial concentration of $\mathrm{CV}$ and $\mathrm{CR}$ solutions with the $\mathrm{pH}$ values from 3 to 11 for a contact time of $360 \mathrm{~min}$. The amount of adsorbed CV and CR depends on the initial $\mathrm{pH}$ of the solution. As the $\mathrm{pH}$ increased from 3 to 11, the adsorbed amount of CV rose, while CR decreased. In acidic media, the $\mathrm{H}^{+}$ions present in the solution protonate the palygorskite surface and the functional groups $(-\mathrm{Si}-\mathrm{OH})$ on its surface to $-\mathrm{Si}-\mathrm{OH}^{2+}$. The competition between $\mathrm{H}^{+}$ions and the $\mathrm{CV}$ cationic dye for the adsorption sites, and the repulsive force between the positively charged adsorbent surface and CV molecules, are considered the factors responsible for the lower adsorption rate of $\mathrm{CV}$ at a low $\mathrm{pH}$ [93].
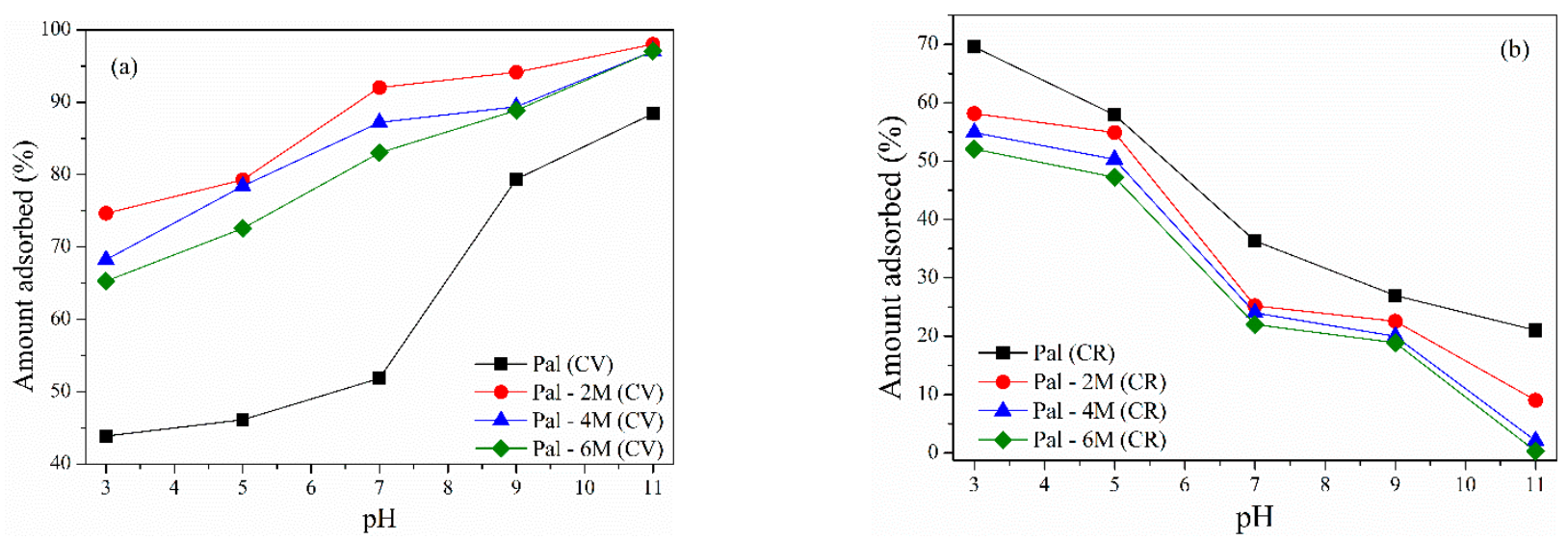

Figure 6. Effect of $\mathrm{pH}$ on (a) CV adsorption and (b) $\mathrm{CR}$ adsorption in palygorskite before and after acid treatment.

On the other hand, negatively charged CR molecules interacted electrostatically with the positively charged surface of the adsorbent at low $\mathrm{pH}$, presenting a higher rate of adsorption [94]. In basic $\mathrm{pH}, \mathrm{OH}^{-}$ions promote the deprotonation of the surface and generate $-\mathrm{Si}-\mathrm{O}^{-}$groups, which favor the adsorption of the positively charged $\mathrm{CV}$ [95]. In addition to competing with $\mathrm{OH}^{-}$ions in basic $\mathrm{pH}, \mathrm{CR}$ molecules are also repelled by the negative surface of the adsorbent, which decreases the adsorption of this anionic dye [96]. At $\mathrm{pH} 11$, the acid-treated samples showed a removal higher than $97 \%$ for $\mathrm{CV}$. At $\mathrm{pH} 3$, the raw and acid-treated samples provided a removal higher than $50 \%$ for CR.

\subsubsection{Effect of Adsorbent Dosage}

Different amounts of adsorbents (10 to $40 \mathrm{mg}$ ) were used for the adsorption of $50 \mathrm{mg} / \mathrm{L}$ of CV and CR. The experiments were performed at $\mathrm{pH} 7$ for $360 \mathrm{~min}$ (see Figure $7 \mathrm{a}, \mathrm{b}$ ). When a small amount of palygorskite was used, the adsorbed amount increased considerably when the adsorbent mass increased from 10 to $40 \mathrm{mg}$. This can be attributed to the increase in the adsorption sites available to remove CV and CR [40,97]. With $40 \mathrm{mg}$ of adsorbent, the CV removal rate reached $82.5 \%, 97.6 \%, 96.9 \%$, and $96.6 \%$ for the Pal, Pal-2M, Pal-4M, and Pal-6M samples, respectively. For the CR, the removal rate was $61.1 \%, 44.1 \%, 30.1 \%$, and 29.2\% for the Pal, Pal-2M, Pal-4M, and Pal-6M samples, respectively.

In Figure 7a, more precisely for the Pal sample, an increase of $30 \%$ was observed on the amount adsorbed for the adsorbent dosages between 20 and $30 \mathrm{mg}$. Such behavior occurs because the carbonate presence probably causes the formation of the agglomerates on the adsorbent. These agglomerates decrease the adsorption efficiency, because a greater amount of interactions between the adsorbate and the absorbent are required for the adsorption to be effective. 

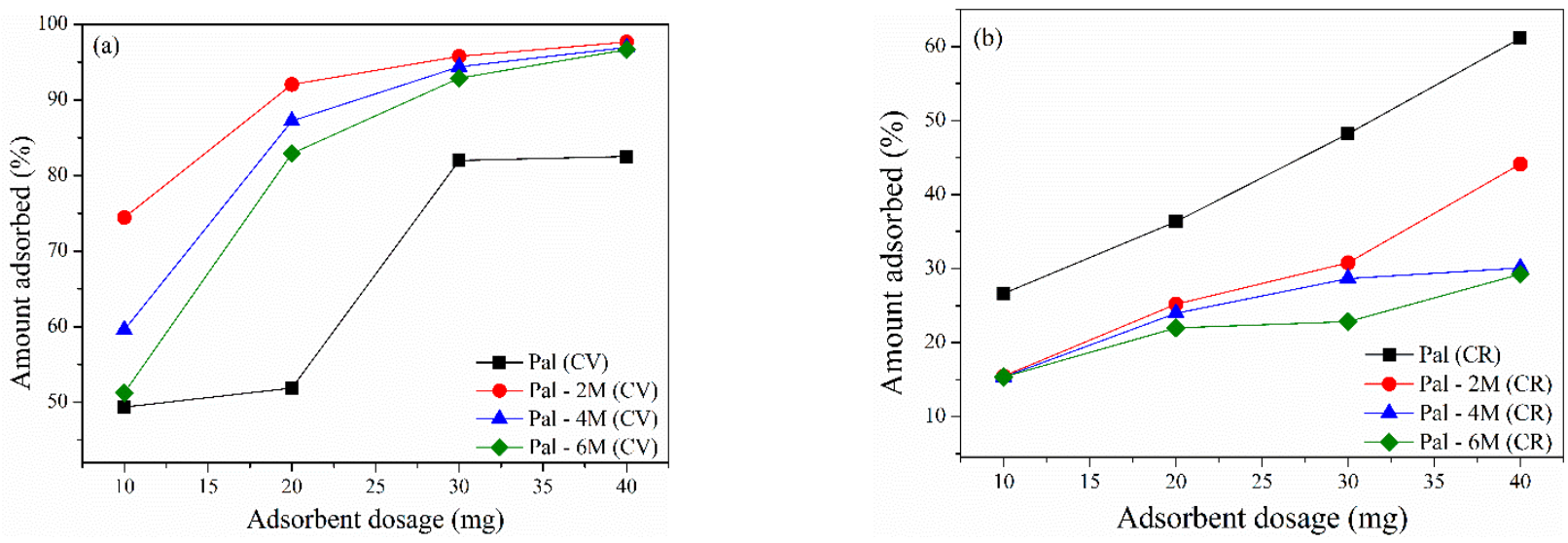

Figure 7. Effect of adsorbent dosage on (a) CV adsorption and (b) CR adsorption in palygorskite before and after acid treatment.

\subsubsection{Effect of Temperature}

Figure 8 shows the temperature effect on the $\mathrm{CV}$ and $\mathrm{CR}$ removal at a temperature range between $25-55{ }^{\circ} \mathrm{C}$. For this, $\mathrm{CV}$ and CR solutions with initial concentrations of $50 \mathrm{mg} / \mathrm{L}$ and a $20 \mathrm{mg}$ clay sample mass were used under $\mathrm{pH}=7$. The adsorbed amounts of $\mathrm{CV}$ and $\mathrm{CR}$ increased slightly with temperature. Such behavior occurs because, at higher temperatures, the kinetic energy of the dye molecules increases, which in turn increases the collision rate of the dye and the clay [98]. Furthermore, the results imply that the CV and $\mathrm{CR}$ adsorptions in the Pal, Pal-2M, Pal-4M, and Pal-6M samples are a predominantly endothermic process, which means that the amount of dye adsorbed increases with higher temperatures [99].
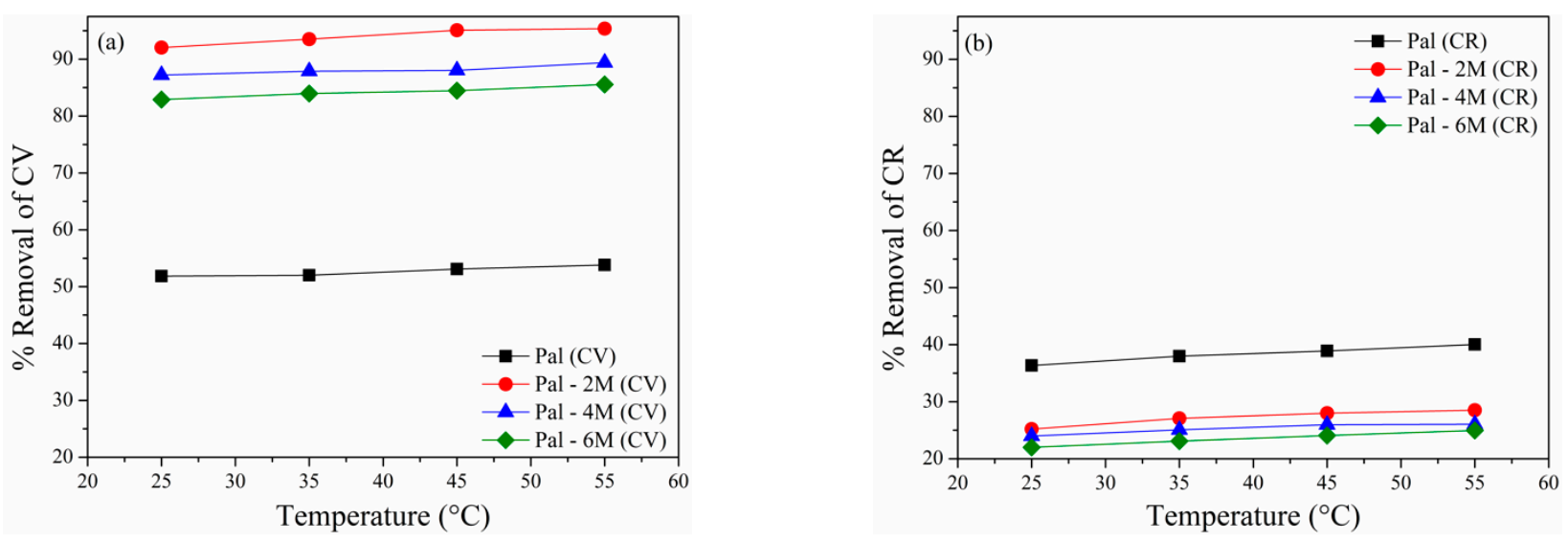

Figure 8. Effect of temperature on (a) CV adsorption and (b) CR adsorption in palygorskite before and after acid treatment.

\subsection{Adsorption Isotherms}

The isothermal adsorption data were adjusted to the Langmuir and Freundlich models (Figure 9a,d and Table 4). Through the values of the correlation coefficients $\left(R^{2}\right)$ and the errors, it was observed that the Langmuir model better described the CV adsorption process. In contrast, the $\mathrm{CR}$ adsorption was better adjusted to the Freundlich model. The best fit of the experimental data of $\mathrm{CV}$ to the Langmuir model suggests that their adsorption occurs mainly via the chemisorption process, with monolayer adsorption on the palygorskite surface $[39,52,100]$. This was not the case for CR adsorption, where Freundlich was a much better fit. This indicates that $\mathrm{CR}$ adsorption on the raw and acid-treated palygorskite occurs on a heterogeneous surface with the formation of multiple layers [101,102]. These data agree with a negative palygorskite surface that favors the chemisorption of cationic dyes, 
such as $\mathrm{CV}$, and the interaction in specific positively charged sites of anionic dyes, such as $\mathrm{CR}$, results in heterogeneous adsorption.
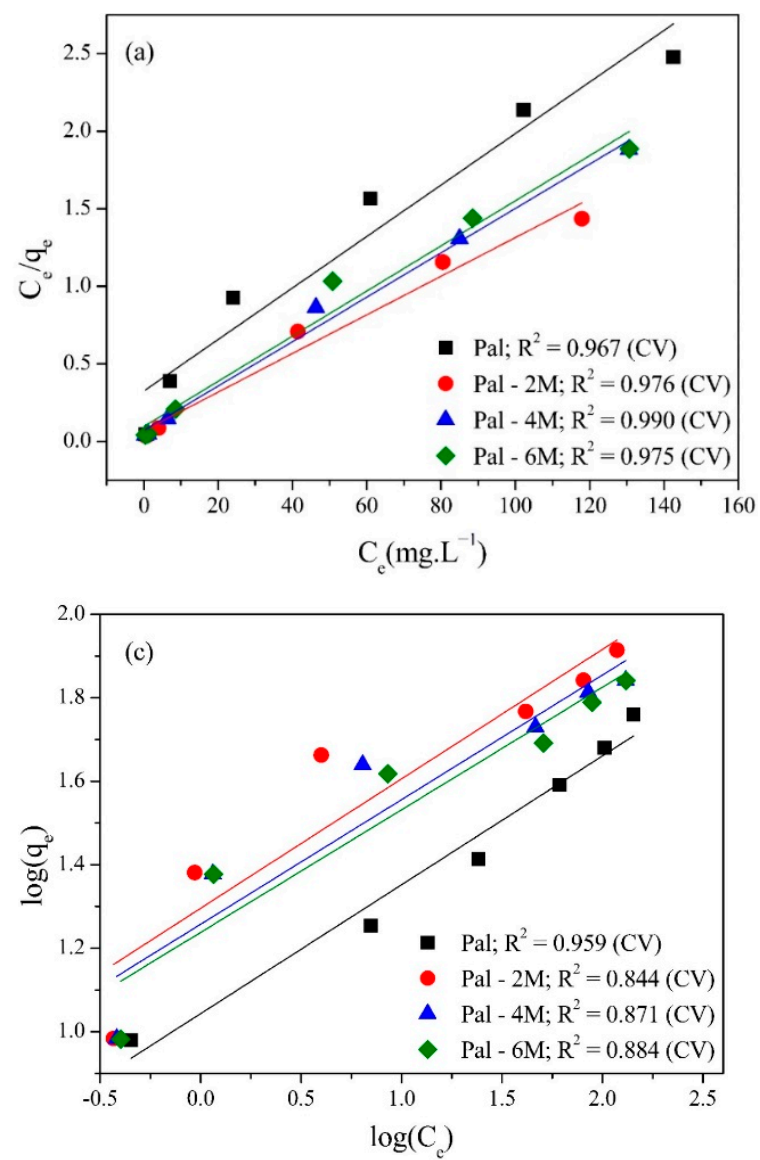
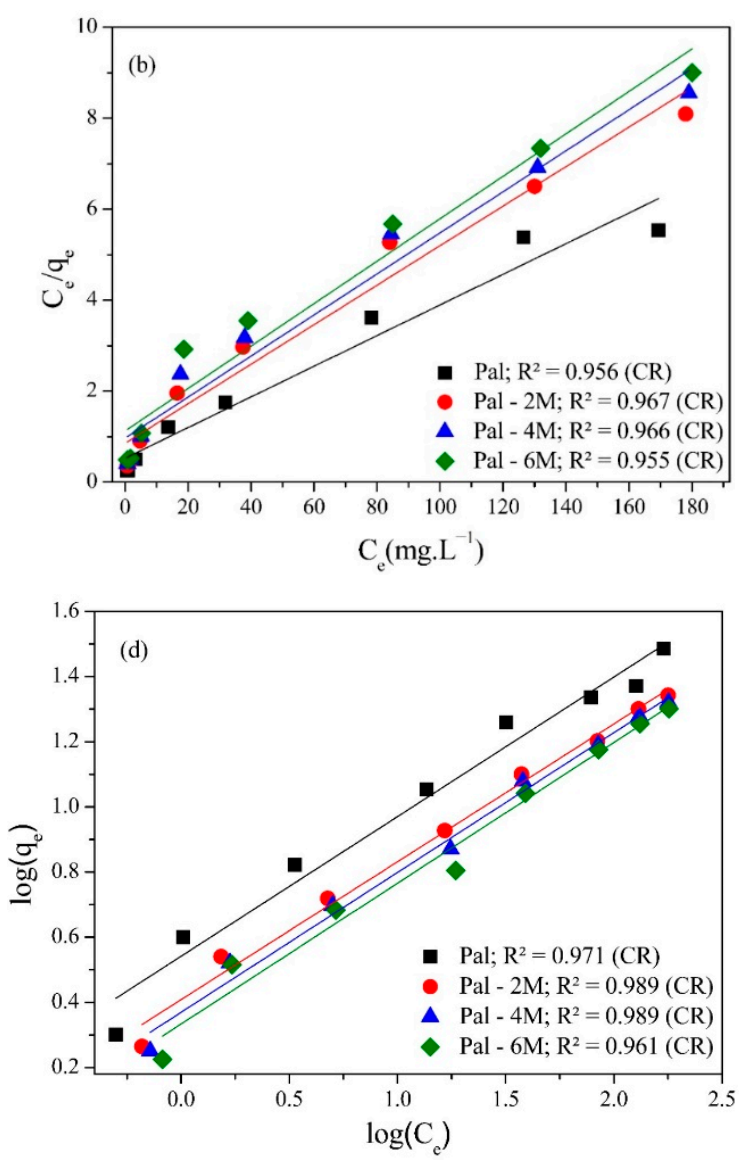

Figure 9. Linear adjustment for CV adsorption and CR adsorption data according to the (a,b) Langmuir and (c,d) Freundlich models.

Table 4. Parameters of Langmuir and Freundlich isothermal models for CV adsorption and CR adsorption.

\begin{tabular}{|c|c|c|c|c|c|c|c|c|}
\hline \multicolumn{5}{|c|}{$\mathrm{CV}$} & \multicolumn{4}{|c|}{ CR } \\
\hline Models & Pal & Pal-2M & Pal-4M & Pal-6M & Pal & Pal-2M & Pal-4M & Pal-6M \\
\hline \multicolumn{9}{|l|}{ Langmuir } \\
\hline $\mathrm{q}_{\max }\left(\mathrm{mg} \cdot \mathrm{g}^{-1}\right)$ & 60.2 & 83.3 & 69.9 & 69.0 & 30.3 & 25.3 & 22.2 & 21.3 \\
\hline $\mathrm{K}_{L}\left(\mathrm{~L} \cdot \mathrm{mg}^{-1}\right)$ & 0.05 & 0.20 & 0.17 & 0.15 & 0.06 & 0.04 & 0.03 & 0.03 \\
\hline$R_{L}$ & 0.09 & 0.03 & 0.02 & 0.03 & 0.08 & 0.11 & 0.14 & 0.14 \\
\hline $\mathrm{R}^{2}$ & 0.967 & 0.976 & 0.990 & 0.975 & 0.956 & 0.967 & 0.966 & 0.955 \\
\hline Error & 0.07 & 0.04 & 0.02 & 0.05 & 1.31 & 1.75 & 1.99 & 2.83 \\
\hline \multicolumn{9}{|l|}{ Freundlich } \\
\hline $1 / \mathrm{n}$ & 031 & 0.31 & 0.30 & 0.30 & 0.43 & 0.44 & 0.43 & 0.43 \\
\hline $\mathrm{K}_{f}\left(\mathrm{mg}^{1-1 / \mathrm{n}} \cdot \mathrm{Kg}^{-1} \cdot \mathrm{L}^{1 / \mathrm{n}}\right)$ & 11.0 & 19.8 & 18.1 & 17.3 & 3.48 & 2.75 & 2.70 & 2.69 \\
\hline $\mathrm{R}^{2}$ & 0.959 & 0.844 & 0.871 & 0.884 & 0.971 & 0.989 & 0.989 & 0.961 \\
\hline Error & 0.09 & 0.08 & 0.06 & 0.06 & 0.03 & 0.01 & 0.01 & 0.02 \\
\hline
\end{tabular}

\subsection{Adsorption Kinetics}

Figure 10a,d and Table 5 show the results obtained from adjusting the kinetic data of $\mathrm{CV}$ and CR adsorption to the pseudo-first-order and pseudo-second-order models. The experimental data were better adjusted to the pseudo-second-order model because the $\mathrm{R}^{2}$ values were the closest to $1\left(\mathrm{R}^{2}>0.990\right)$. The calculated $\mathrm{q}_{e}$ agreed with the experimental data 
$\left(\mathrm{q}_{\text {exp }}\right)$. These results indicate that adsorption in palygorskite samples can be determined mainly by chemisorption, involving the sharing or transfer of electrons $[103,104]$.
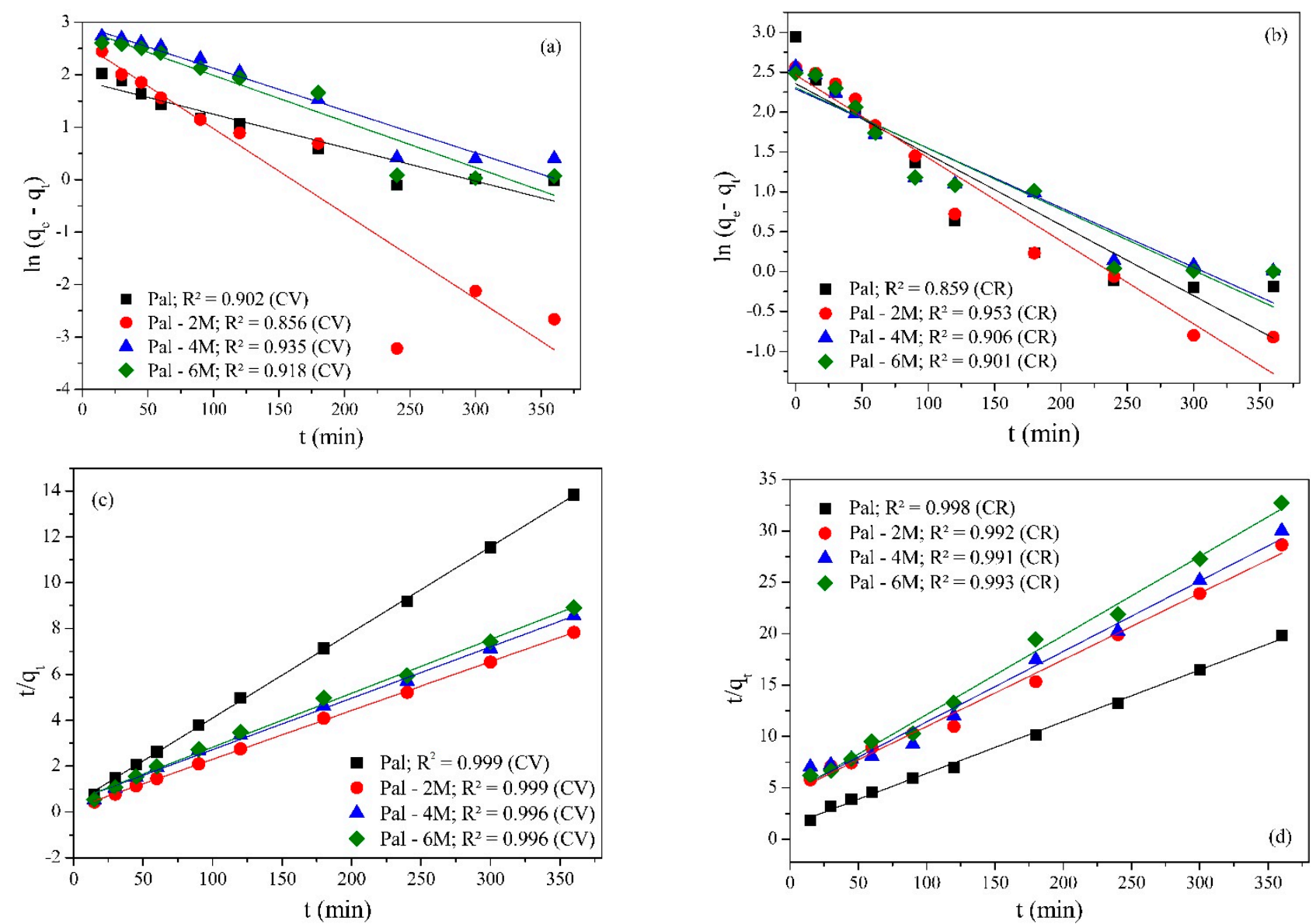

Figure 10. Linear adjustment of $(\mathbf{a}, \mathbf{b})$ pseudo-first-order and $(\mathbf{c}, \mathbf{d})$ pseudo-second-order kinetic models for CV adsorption and CR adsorption.

Table 5. Kinetic parameters of pseudo-first-order and pseudo-second-order models for CV adsorption and CR adsorption.

\begin{tabular}{|c|c|c|c|c|c|c|c|c|}
\hline \multirow[b]{2}{*}{ Models } & \multirow[b]{2}{*}{ Pal } & \multicolumn{3}{|c|}{ CV } & \multicolumn{4}{|c|}{ CR } \\
\hline & & Pal-2M & Pal-4M & Pal-6M & Pal & Pal-2M & Pal-4M & Pal-6M \\
\hline \multicolumn{9}{|l|}{ Pseudo-first-order } \\
\hline $\mathrm{q}_{e, \exp }\left(\mathrm{mg} \cdot \mathrm{g}^{-1}\right)$ & 25.97 & 45.98 & 42.08 & 40.36 & 18.17 & 12.56 & 11.99 & 11.01 \\
\hline $\mathrm{q}_{e, \text { cal }}\left(\mathrm{mg} \mathrm{g}^{-1}\right)$ & 77.31 & 194.17 & 126.30 & 112.06 & 126.46 & 208.40 & 190.55 & 199.52 \\
\hline $\mathrm{k}_{1}\left(\min ^{-1}\right)$ & 0.02 & 0.04 & 0.02 & 0.02 & 0.02 & 0.02 & 0.01 & 0.02 \\
\hline$R^{2}$ & 0.902 & 0.856 & 0.935 & 0.918 & 0.859 & 0.953 & 0.906 & 0.901 \\
\hline Error & 0.51 & 5.17 & 0.53 & 0.81 & 2.67 & 3.96 & 7.26 & 4.66 \\
\hline \multicolumn{9}{|c|}{ Pseudo-second-order } \\
\hline $\mathrm{q}_{e, c a l}\left(\mathrm{mg} \cdot \mathrm{g}^{-1}\right)$ & 26.76 & 46.95 & 44.62 & 42.52 & 20.02 & 15.46 & 14.71 & 13.01 \\
\hline $\mathrm{k}_{2}\left(\min ^{-1}\right)$ & 3.87 & 2.74 & 1.05 & 1.17 & 0.04 & 0.02 & 0.02 & 0.02 \\
\hline$R^{2}$ & 0.999 & 0.999 & 0.996 & 0.996 & 0.998 & 0.992 & 0.991 & 0.993 \\
\hline Error & 0.07 & 0.02 & 0.21 & 0.27 & 1.70 & 0.72 & 0.77 & 0.86 \\
\hline
\end{tabular}

\subsection{Adsorption Thermodynamics}

The $\Delta \mathrm{H}$ and $\Delta \mathrm{S}$ values were calculated from the slope and intercept of the $\ln \mathrm{K}_{\mathrm{d}}$ versus $1 / \mathrm{T}$ plot (Figure 11a,b). The $\Delta \mathrm{H}, \Delta \mathrm{S}$, and $\Delta \mathrm{G}$ (Equation (8)) values are listed in Tables 6 and 7 . Adsorption processes with positive $\Delta \mathrm{H}$ values are predominantly endothermic [42]. Therefore, from experimental data shown in Tables 6 and 7, it is easy to conclude 
that $\mathrm{CV}$ and $\mathrm{CR}$ dyes' adsorption processes in the Pal, Pal-2M, Pal-4M, and Pal-6M samples are predominantly endothermic. The negative $\Delta \mathrm{G}$ values measured indicated that the adsorption of both dyes in the samples studied was viable and spontaneous thermodynamically [57]. In addition, the positive $\Delta \mathrm{S}$ values indicated an increased randomness and disorder of the adsorbent surface after adsorption [105].
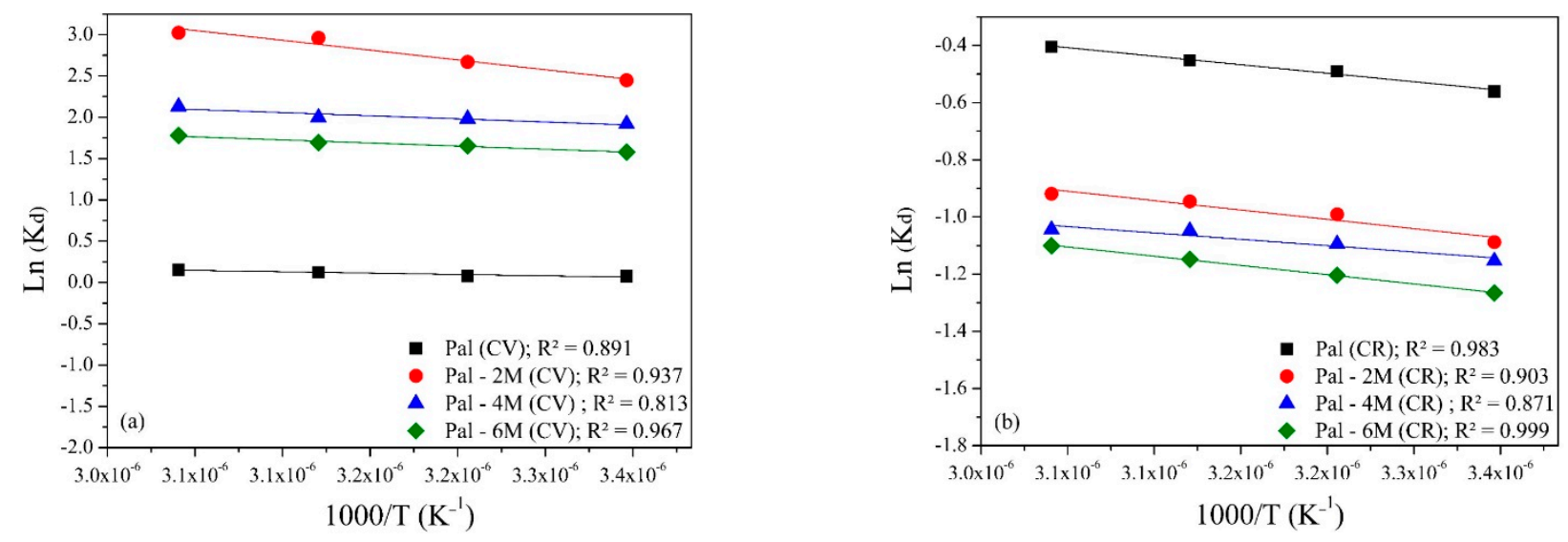

Figure 11. Van't Hoff plot for the removal of (a) CV and (b) CR dyes.

Table 6. Thermodynamic parameters for the adsorption of CV dye in the palygorskite samples.

\begin{tabular}{|c|c|c|c|c|c|c|}
\hline \multirow{2}{*}{ Sample } & \multicolumn{4}{|c|}{$\Delta \mathrm{G}\left(\mathrm{kJ} \mathrm{mol}^{-1}\right)$} & \multirow{2}{*}{$\Delta \mathrm{H}\left(\mathrm{kJ} \mathrm{mol}^{-1}\right)$} & \multirow{2}{*}{$\Delta S\left(\mathrm{~J} \mathrm{k}^{-1} \mathrm{~mol}^{-1}\right)$} \\
\hline & $298 \mathrm{~K}$ & $308 \mathrm{~K}$ & $318 \mathrm{~K}$ & $328 \mathrm{~K}$ & & \\
\hline $\mathrm{Pal}$ & -0.17 & -0.20 & -0.32 & -0.41 & 0.27 & 0.97 \\
\hline Pal-2M & -6.07 & -6.83 & -7.82 & -8.23 & 1.98 & 9.11 \\
\hline Pal-4M & -4.75 & -5.01 & -5.29 & -5.81 & 0.63 & 4.02 \\
\hline Pal-6M & -3.91 & -4.25 & 4.47 & -4.82 & 0.62 & 3.67 \\
\hline
\end{tabular}

Table 7. Thermodynamic parameters for the adsorption of CR dye in the palygorskite samples.

\begin{tabular}{|c|c|c|c|c|c|c|}
\hline \multirow{2}{*}{ Sample } & \multicolumn{4}{|c|}{$\Delta \mathrm{G}\left(\mathrm{kJ} \mathrm{mol} \mathrm{m}^{-1}\right)$} & \multirow{2}{*}{$\Delta \mathrm{H}\left(\mathrm{kJ} \mathrm{mol}{ }^{-1}\right)$} & \multirow{2}{*}{$\Delta S\left(\mathrm{~J} \mathrm{k}^{-1} \mathrm{~mol}^{-1}\right)$} \\
\hline & $298 \mathrm{~K}$ & $308 \mathrm{~K}$ & $318 \mathrm{~K}$ & $328 \mathrm{~K}$ & & \\
\hline Pal & -1.41 & -1.56 & -1.69 & -1.83 & 0.49 & 1.11 \\
\hline Pal-2M & -0.82 & -0.95 & -1.03 & -1.09 & 0.54 & 0.76 \\
\hline Pal-4M & -0.77 & -0.84 & -0.92 & -0.95 & 0.37 & 0.11 \\
\hline Pal-6M & -0.69 & -0.77 & -0.85 & -0.89 & 0.54 & 0.54 \\
\hline
\end{tabular}

\subsection{Characterization after Adsorption}

The FTIR spectra acquired from the Pal and Pal-2M samples before and after the adsorption of CV and CR are shown in Figure 12a,b. After the CV dye's adsorption on the Pal and Pal-2M samples (Figure 12a), new bands were detected at $1588 \mathrm{~cm}^{-1}$ and $1366 \mathrm{~cm}^{-1}$. These bands were due to the stretching vibrations $\mathrm{C}=\mathrm{C}$ and $\mathrm{C}-\mathrm{N}$ that are characteristic of the CV dye $[106,107]$. Such bands confirm the removal of the CV dye molecules from the aqueous solution after adsorption by chemisorption [108].

Figure 12b shows that the FTIR spectra measured from the Pal and Pal-2M samples did not change significantly after CR's adsorption. This indicates that there was no breakage or formation of new bonds after adsorption, suggesting the occurrence of physical adsorption (physisorption) in the adsorption of the CR dye [14]. 


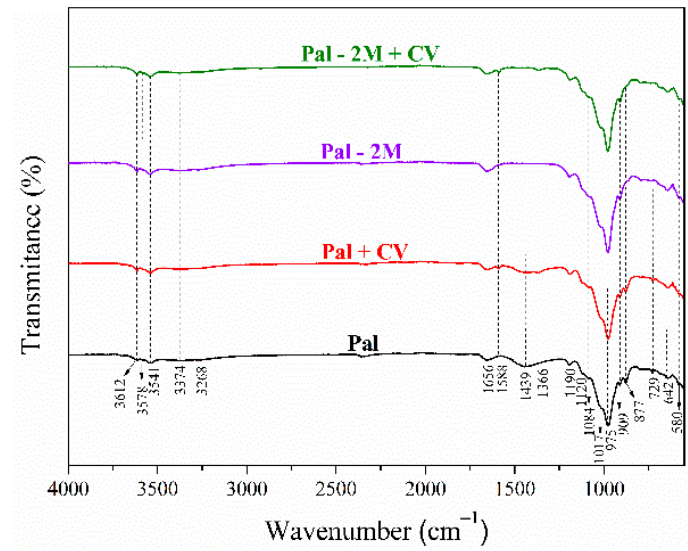

(a)

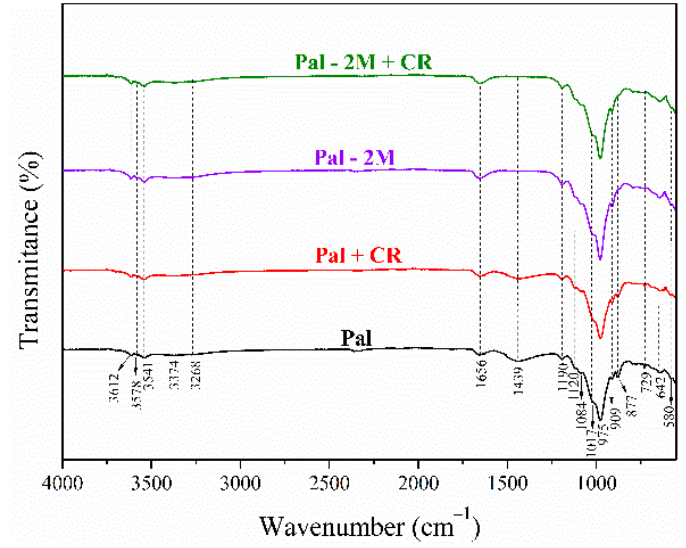

(b)

Figure 12. FTIR spectra of the Pal and Pal-2M samples before and after the adsorption of (a) CV and (b) CR dyes.

The different chemical structures of the dyes result in different forms of bonding on the adsorbent's surface [33]. Figure 13 illustrates the interaction of the CV and CR dye molecules on the palygorskite surface. The positively charged CV molecules are likely to bind almost perpendicular to the clay surface. Conversely, negatively charged CR molecules are likely to bind perpendicularly to the surface. Thus, the molecular structure of the dye also influences the adsorption capacity of the adsorbent.

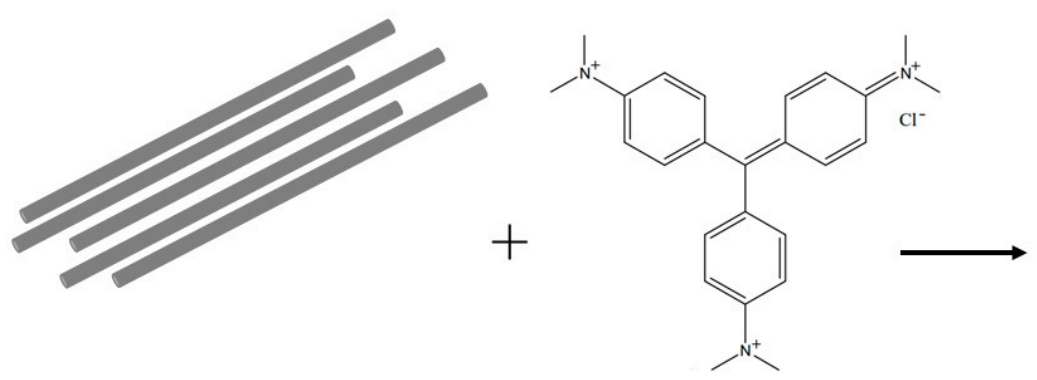

Palygorskite clay

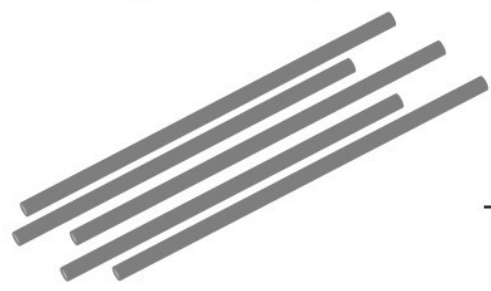

Palygorskite clay
Chemical structure of $\mathrm{CV}$

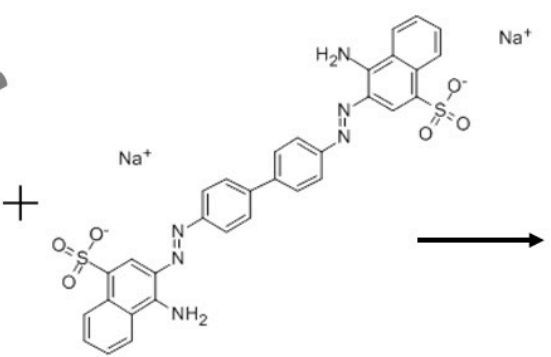

Chemical structure of CR

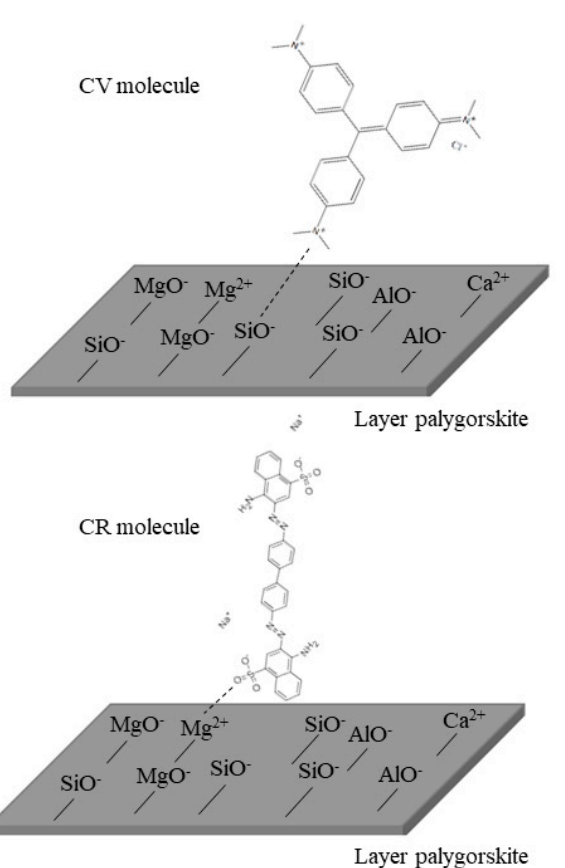

Layer palygorskite

Figure 13. Schema of the interaction between the raw and acid-treated palygorskite surface and CV and CR dyes.

\subsection{Regeneration Study}

To evaluate the reuse of the $\mathrm{Pal}$ and $\mathrm{Pal}-2 \mathrm{M}$ samples, $1 \mathrm{M}$ of $\mathrm{CH}_{3} \mathrm{COOH}$ was used to regenerate the adsorbent adsorption sites. After desorption, the regenerated adsorbent was reused for four cycles. The results are shown in Figure 14a,b. Figure 14a shows the effect of regeneration on the adsorption capacity of Pal and Pal-2M samples for $\mathrm{CV}$ removal. After four cycles, the decrease in CV removal efficiency was less than $20 \%$ for both samples, going from $52 \%$ to $30 \%$ and from $92 \%$ for $76 \%$ for Pal and Pal-2M, respectively. Figure $14 \mathrm{~b}$ shows the effect of regeneration on the adsorption capacity of the Pal and Pal-2M samples 
for CR removal. After four cycles, the decrease in CR removal efficiency was also less than $20 \%$ for both samples, going from $36 \%$ to $20 \%$ and from $25 \%$ for $10 \%$ for the Pal and Pal- $2 \mathrm{M}$ samples, respectively.
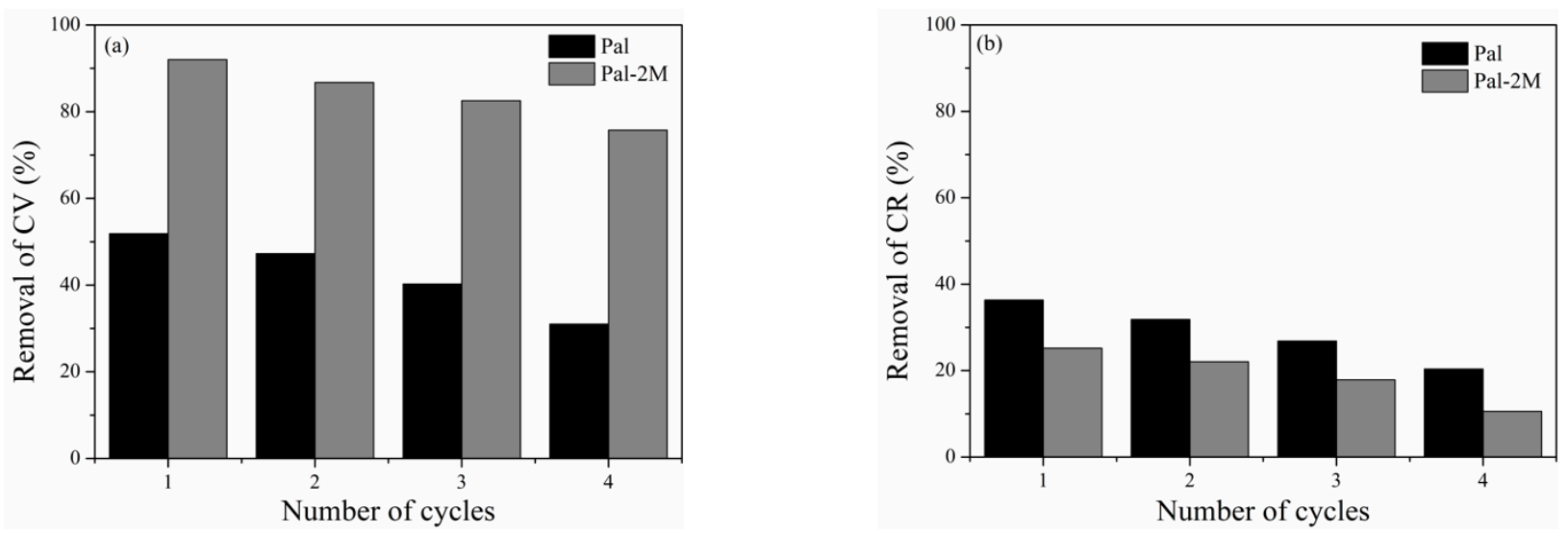

Figure 14. Reusability of the Pal and Pal-2M in four cycles for the removal (a) CV and (b) CR dyes.

The decrease in the efficiency of Pal and Pal-2M for removing CV and CR dyes occurs due to the dye molecules not being completely released by desorption; some of them may have remained, resulting in repulsive forces for the new dye molecules [99].

\subsection{Comparison with Other Adsorbents}

Figure 15 compares the maximum amount of $\mathrm{CR}$ dye adsorbed in the raw and acidtreated Brazilian palygorskite (Pal, Pal-2M, Pal-4M, and Pal-6M) with works published elsewhere that worked with other adsorbents. For example, the $\mathrm{Zn} / \mathrm{SiO}_{2}$ composite presented a maximum amount of CR adsorbed equal to $83 \mathrm{mg} / \mathrm{g}$ [109]; the maximum amount of CR absorbed by chitosan hydrogels was $44.2 \mathrm{mg} / \mathrm{g}$ [110], by kaolin it was $5.94 \mathrm{mg} / \mathrm{g}$ [111], and by amino-functionalized silica gel it was $10 \mathrm{mg} / \mathrm{g}$ [112]. These experimental results indicate that the Brazilian palygorskite has a competitive adsorption capacity for the CR dye.

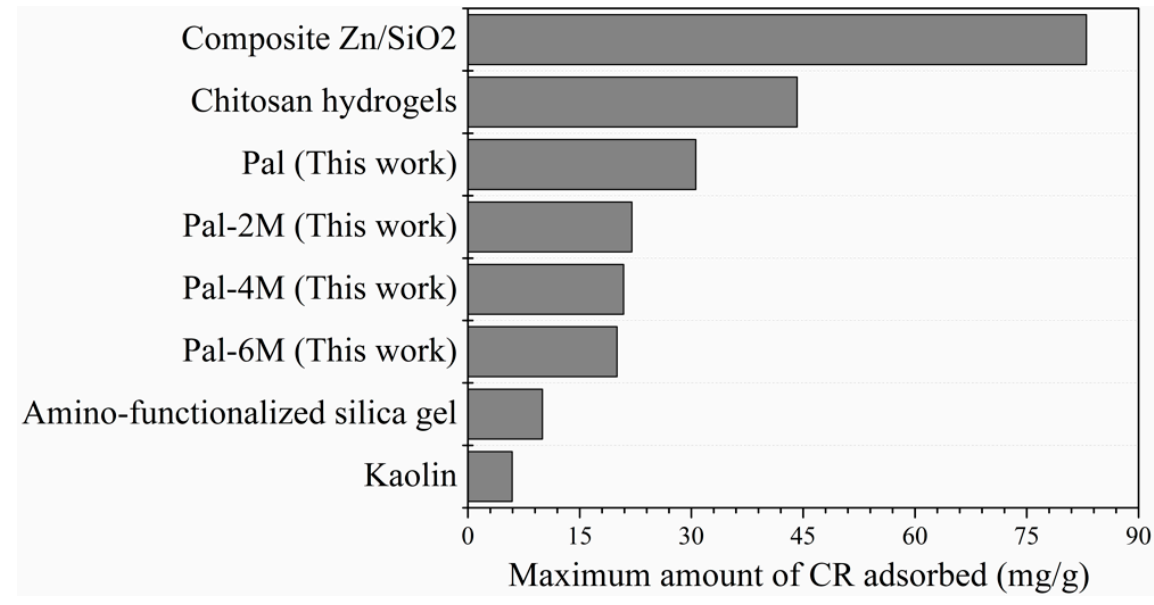

Figure 15. Comparison of the adsorption capacity of different adsorbents for the CR.

Compared with the Pal sample, the Pal-2M, Pal-4M, and Pal-6M samples presented higher CV adsorption capacities. The Pal-2M presented a high adsorption capacity $(82.1 \mathrm{mg} / \mathrm{g}) . \quad$ CV adsorption studies accomplished with others adsorbents presented the following CV adsorption capacities (Figure 16): chitosan-graphite oxide-modified polyurethane $(1.98 \mathrm{mg} / \mathrm{g})$ [113], titanate nanotubes $(8.36 \mathrm{mg} / \mathrm{g})$ [114], nano mesocellular foam silica $(6.64 \mathrm{mg} / \mathrm{g})$ [115], Moroccan clay $(17.05 \mathrm{mg} / \mathrm{g})$ [116], magnetically modified ac- 
tivated carbon (67.1 mg/g) [117], Chinese palygorskite treated with $\mathrm{HCl}$ [33] (180.24 mg/g) and Oman palygorskite $(70 \mathrm{mg} / \mathrm{g})$ [41]. Palygorskites from different regions showed better $\mathrm{CV}$ adsorption performances when compared to synthetic adsorbents. The Pal-2M sample showed a lower CV adsorptive capacity when compared to acid-treated Chinese palygorskite [33]. Even so, it presented an adsorption capacity superior to that of other adsorbents found in the literature. This depicts the potential of acid-treated Brazilian palygorskite to be used in the treatment of dye-contaminated wastewater.

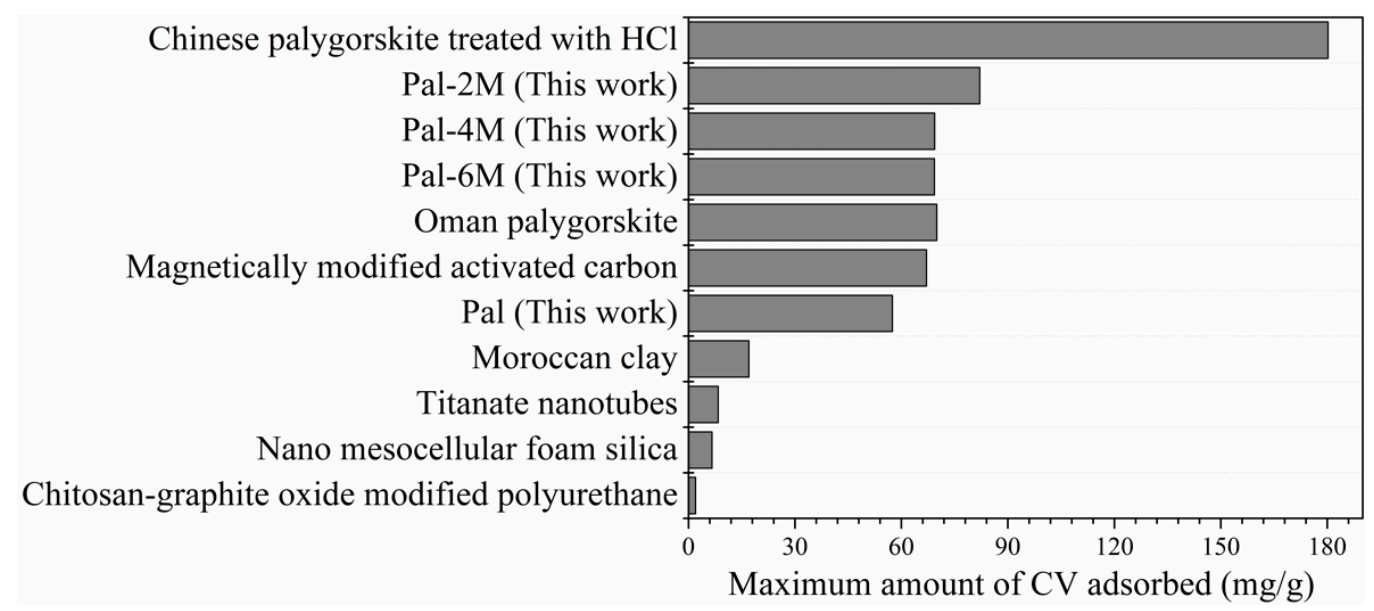

Figure 16. Comparison of the adsorption capacity of different adsorbents for the CV.

Clays are materials with the potential to green the world of materials in the 21st century because of their sustainable character [93]. Thus, the acid-treated palygorskite is a sustainable alternative for the treatment of water contaminated with dyes. The modification technique used in this work is simple, relatively economical, easy to operate, and able to produce adsorption capacities equivalent to those obtained using complex and expensive methods and non-sustainable adsorbent materials. However, only raw palygorskite, as observed in other works, does not seem to be the most efficient adsorption material. The acid-treated palygorskite is an interesting alternative to produce efficient adsorption systems to treat dye-contaminated water.

\section{Conclusions}

In this study, the crystal violet (CV) adsorption and congo red (CR) dyes on raw and acid-treated Brazilian palygorskite were successfully evaluated. Experiments of chemical analysis, X-ray diffraction, and FTIR showed that the acid treatment used did not destroy the structure of the studied dioctahedral-trioctahedral character palygorskite. Adsorption behavior was not directly associated with BET, and samples treated with the lowest acid concentration solution (2M) showed good efficiency for the cationic dye's adsorption. In basic $\mathrm{pH}$, the acid-treated sample removed almost all the $\mathrm{CV}$ dye $(97 \%)$. In acid $\mathrm{pH}$, the removal of the CR dye was greater than $50 \%$. From a thermodynamics viewpoint, the $\mathrm{CV}$ and $\mathrm{CR}$ dyes are predominantly endothermic, viable, and spontaneous. The FTIR spectra performed after the CV dye's adsorption on the Pal and Pal-2M samples identified the appearance of new bands at $1588 \mathrm{~cm}^{-1}$ and $1366 \mathrm{~cm}^{-1}$, respectively. Such bands confirm the removal of the CV dye molecules from the aqueous solution after adsorption by chemisorption. On the other hand, the FTIR spectra measured from the Pal and Pal-2M samples after adsorption of the CR dye indicated that there was no breakage or formation of new bonds after adsorption, suggesting the occurrence of physical adsorption (physisorption) in the adsorption of the CR dye. The adsorbents derived from Brazilian palygorskite proved to be promising candidates for removing cationic and anionic dyes from water. 
Author Contributions: Experimental data, data curation, and formal analysis, V.C.S., M.E.B.A., A.M.R. and R.R.M.; conceptualization, funding acquisition, and project administration, G.A.N., R.R.M. and J.M.C.; formal analysis and writing-review and editing, V.C.S., R.R.M. and A.M.R. All authors have read and agreed to the published version of the manuscript.

Funding: This research was funded by the Coordenação de Aperfeiçoamento de Pessoal e Nível Superior-Brasil (CAPES)-Finance Code 001 (scholarship granted to Vanderlane Cavalcanti da Silva), grant number 88882.455338/2019-01, and National Council for Scientific and Technological Development (CNPq), grant numbers 126892/2020-2, 308822/2018-8, and 420004/2018-1.

Institutional Review Board Statement: Not applicable.

Informed Consent Statement: Not applicable.

Data Availability Statement: Not applicable.

Conflicts of Interest: The authors declare no conflict of interest.

\section{References}

1. Goh, P.S.; Ismail, A.F. A review on inorganic membranes for desalination and wastewater treatment. Desalination 2018, 434, 60-80. [CrossRef]

2. Mirza, A.; Ahmad, R. An efficient sequestration of toxic crystal violet dye from aqueous solution by Alginate/Pectin nanocomposite: A novel and ecofriendly adsorbent. Groundw. Sustain. Dev. 2020, 11, 100373. [CrossRef]

3. Tyagi, U. Adsorption of dyes using activated carbon derived from pyrolysis of vetiveria zizanioides in a fixed bed reactor. Groundw. Sustain. Dev. 2020, 10, 100303. [CrossRef]

4. Sirajudheen, P.; Meenakshi, S. Lanthanum (III) incorporated chitosan-montmorillonite composite as flexible material for adsorptive removal of azo dyes from water. Mater. Today Proc. 2020, 27, 318-326. [CrossRef]

5. Elella, M.H.A.; Sabaa, M.W.; Abd ElHafeez, E.; Mohamed, R.R. Crystal violet dye removal using crosslinked grafted xanthan gum. Int. J. Biol. Macromol. 2019, 137, 1086-1101. [CrossRef] [PubMed]

6. Ahmad, R.; Ansari, K. Polyacrylamide-Grafted Actinidia deliciosa peels powder (PGADP) for the sequestration of crystal violet dye: Isotherms, kinetics and thermodynamic studies. Appl. Water Sci. 2020, 10, 1-15. [CrossRef]

7. Cheruiyot, G.K.; Wanyonyi, W.C.; Kiplimo, J.J.; Maina, E.N. Adsorption of toxic crystal violet dye using coffee husks: Equilibrium, kinetics and thermodynamics study. Sci. Afr. 2019, 5, e00116. [CrossRef]

8. Ebrahimpour, M.; Hassaninejad-Darzi, S.K.; Zavvar Mousavi, H. Adsorption of ternary toxic crystal violet, malachite green and methylene blue onto synthesised SBA-15 mesoporous nanoparticles. Int. J. Environ. Anal. Chem. 2020, 1-24. [CrossRef]

9. Pang, X.; Sellaoui, L.; Franco, D.; Dotto, G.L.; Georgin, J.; Bajahzar, A.; Belmabrouk, H.; Lamine, A.B.; Bonilla-Petriciolet, A.; Li, Z. Adsorption of crystal violet on biomasses from pecan nutshell, para chestnut husk, araucaria bark and palm cactus: Experimental study and theoretical modeling via monolayer and double layer statistical physics models. Chem. Eng. J. 2019, 378, 122101. [CrossRef]

10. Sadeghi, S.; Nasehi, Z. Simultaneous determination of Brilliant Green and Crystal Violet dyes in fish and water samples with dispersive liquid-liquid micro-extraction using ionic liquid followed by zero crossing first derivative spectrophotometric analysis method. Spectrochim. Acta Part A Mol. Biomol. Spectrosc. 2018, 201, 134-142. [CrossRef]

11. Ciobanu, G.; Harja, M.; Diaconu, M.; Cimpeanu, C.; Teodorescu, R.; Bucur, D. Crystal violet dye removal from aqueous solution by nanohydroxyapatite. J. Food Agric. Environ. 2014, 12, 499-502.

12. Mani, S.; Bharagava, R.N. Exposure to crystal violet, its toxic, genotoxic and carcinogenic effects on environment and its degradation and detoxification for environmental safety. Rev. Environ. Contamin. Toxicol. 2016, 237, 71-104.

13. Kulkarni, M.R.; Revanth, T.; Acharya, A.; Bhat, P. Removal of Crystal Violet dye from aqueous solution using water hyacinth: Equilibrium, kinetics and thermodynamics study. Resour. Technol. 2017, 3, 71-77. [CrossRef]

14. Li, Z.; Hanafy, H.; Zhang, L.; Sellaoui, L.; Netto, M.S.; Oliveira, M.L.S.; Seliem, M.K.; Dotto, G.L.; Bonilla-Petriciolet, A.; Li, Q. Adsorption of congo red and methylene blue dyes on an ashitaba waste and a walnut shell-based activated carbon from aqueous solutions: Experiments, characterization and physical interpretations. Chem. Eng. J. 2020, 388, 124263. [CrossRef]

15. Gupta, V.K.; Agarwal, S.; Ahmad, R.; Mirza, A.; Mittal, J. Sequestration of toxic congo red dye from aqueous solution using ecofriendly guar gum/activated carbon nanocomposite. Int. J. Biol. Macromol. 2020, 158, 1310-1318. [CrossRef]

16. Swan, N.B.; Zaini, M.A.A. Adsorption of malachite green and congo red dyes from water: Recent progress and future outlook. Ecol. Chem. Eng. S 2019, 26, 119-132. [CrossRef]

17. Elwakeel, K.Z.; Elgarahy, A.M.; Elshoubaky, G.A.; Mohammad, S.H. Microwave assist sorption of crystal violet and Congo red dyes onto amphoteric sorbent based on upcycled Sepia shells. J. Environ. Health Sci. Eng. 2020, 18, 35-50. [CrossRef]

18. Zhang, Q.; Yan, Z.; Ouyang, J.; Zhang, Y.; Yang, H.; Chen, D. Chemically modified kaolinite nanolayers for the removal of organic pollutants. Appl. Clay Sci. 2018, 157, 283-290. [CrossRef]

19. Kirankumar, V.S.; Sumathi, S. Copper and cerium co-doped cobalt ferrite nanoparticles: Structural, morphological, optical, magnetic, and photocatalytic properties. Environ. Sci. Pollut. Res. 2019, 26, 19189-19206. [CrossRef] 
20. Cao, X.-L.; Yan, Y.-N.; Zhou, F.-Y.; Sun, S.-P. Tailoring nanofiltration membranes for effective removing dye intermediates in complex dye-wastewater. J. Membr. Sci. 2020, 595, 117476. [CrossRef]

21. Bouras, H.D.; Isik, Z.; Arikan, E.B.; Bouras, N.; Chergui, A.; Yatmaz, H.C.; Dizge, N. Photocatalytic oxidation of azo dye solutions by impregnation of $\mathrm{ZnO}$ on fungi. Biochem. Eng. J. 2019, 146, 150-159. [CrossRef]

22. Zhou, F.; Cheng, Y.; Gan, L.; Chen, Z.; Megharaj, M.; Naidu, R. Burkholderia vietnamiensis C09V as the functional biomaterial used to remove crystal violet and Cu (II). Ecotoxicol. Environ. Saf. 2014, 105, 1-6. [CrossRef]

23. Baddouh, A.; El Ibrahimi, B.; Rguitti, M.M.; Mohamed, E.; Hussain, S.; Bazzi, L. Electrochemical removal of methylene bleu dye in aqueous solution using Ti/RuO2-IrO2 and SnO2 electrodes. Sep. Sci. Technol. 2019, 1-10. [CrossRef]

24. Yang, H.-C.; Gong, J.-L.; Zeng, G.-M.; Zhang, P.; Zhang, J.; Liu, H.-Y.; Huan, S.-Y. Polyurethane foam membranes filled with humic acid-chitosan crosslinked gels for selective and simultaneous removal of dyes. J. Colloid Interface Sci. 2017, 505, 67-78. [CrossRef]

25. Wang, Y.; Su, X.; Xu, Z.; Wen, K.; Zhang, P.; Zhu, J.; He, H. Preparation of surface-functionalized porous clay heterostructures via carbonization of soft-template and their adsorption performance for toluene. Appl. Surf. Sci. 2016, 363, 113-121. [CrossRef]

26. Sana, D.; Jalila, S. A comparative study of adsorption and regeneration with different agricultural wastes as adsorbents for the removal of methylene blue from aqueous solution. Chin. J. Chem. Eng. 2017, 25, 1282-1287. [CrossRef]

27. Shi, C.; Tao, F.; Cui, Y. Evaluation of nitriloacetic acid modified cellulose film on adsorption of methylene blue. Int. J. Biol. Macromol. 2018, 114, 400-407. [CrossRef]

28. Tang, J.; Mu, B.; Zong, L.; Wang, A. From waste hot-pot oil as carbon precursor to development of recyclable attapulgite/carbon composites for wastewater treatment. J. Environ. Sci. 2019, 75, 346-358. [CrossRef] [PubMed]

29. Jiang, H.-L.; Xu, M.-Y.; Xie, Z.-W.; Hai, W.; Xie, X.-L.; He, F.-A. Selective adsorption of anionic dyes from aqueous solution by a novel $\beta$-cyclodextrin-based polymer. J. Mol. Struct. 2020, 1203, 127373. [CrossRef]

30. Fernandes, J.V.; Rodrigues, A.M.; Menezes, R.R.; Neves, G.D.A. Adsorption of Anionic Dye on the Acid-Functionalized Bentonite. Materials 2020, 13, 3600. [CrossRef]

31. Buburuzan, A.M.; Catrinescu, C.; Macoveanu, M. Comparative study of the adsorption-desorption cycles of hexane over hypercrosslinked polymeric adsorbents and activated carbon. Environ. Eng. Manag. J. 2010, 9, 125-132. [CrossRef]

32. Zhu, J.; Zhang, P.; Wang, Y.; Wen, K.; Su, X.; Zhu, R.; He, H.; Xi, Y. Effect of acid activation of palygorskite on their toluene adsorption behaviors. Appl. Clay Sci. 2018, 159, 60-67. [CrossRef]

33. Yang, R.; Li, D.; Li, A.; Yang, H. Adsorption properties and mechanisms of palygorskite for removal of various ionic dyes from water. Appl. Clay Sci. 2018, 151, 20-28. [CrossRef]

34. Azha, S.F.; Sellaoui, L.; Yunus, E.H.E.; Yee, C.J.; Bonilla-Petriciolet, A.; Lamine, A.B.; Ismail, S. Iron-modified composite adsorbent coating for azo dye removal and its regeneration by photo-Fenton process: Synthesis, characterization and adsorption mechanism interpretation. Chem. Eng. J. 2019, 361, 31-40. [CrossRef]

35. Piri, F.; Mollahosseini, A.; Hosseini, M.M. Enhanced adsorption of dyes on microwave-assisted synthesized magnetic zeolitehydroxyapatite nanocomposite. J. Environ. Chem. Eng. 2019, 7, 103338. [CrossRef]

36. Xinguo, X.; Jiling, Z.; Ruiyu, J.; Qi, X. Application of Modified Attapulgite Clay as the Adsorbent in Gasoline Desulfurization. China Pet. Process. Petrochem. Technol. 2014, 16, 63-68.

37. Han, J.; Liang, X.; Xu, Y.; Xu, Y. Removal of $\mathrm{Cu} 2+$ from aqueous solution by adsorption onto mercapto functionalized palygorskite. J. Ind. Eng. Chem. 2015, 23, 307-315. [CrossRef]

38. Zhang, Y.; Wang, W.; Zhang, J.; Liu, P.; Wang, A. A comparative study about adsorption of natural palygorskite for methylene blue. Chem. Eng. J. 2015, 262, 390-398. [CrossRef]

39. Câmara, A.B.F.; Sales, R.V.; Bertolino, L.C.; Furlanetto, R.P.P.; Rodríguez-Castellón, E.; De Carvalho, L.S. Novel application for palygorskite clay mineral: A kinetic and thermodynamic assessment of diesel fuel desulfurization. Adsorption 2020, 26, 267-282 [CrossRef]

40. Huang, D.; Zheng, Y.; Zhang, Z.; Quan, Q.; Qiang, X. Synergistic effect of hydrophilic palygorskite and hydrophobic zein particles on the properties of chitosan films. Mater. Des. 2020, 185, 108229. [CrossRef]

41. Al-Futaisi, A.; Jamrah, A.; Al-Hanai, R. Aspects of cationic dye molecule adsorption to palygorskite. Desalination 2007, 214, 327-342. [CrossRef]

42. Youcef, L.D.; Belaroui, L.S.; López-Galindo, A. Adsorption of a cationic methylene blue dye on an Algerian palygorskite. Appl. Clay Sci. 2019, 179, 105145. [CrossRef]

43. Abidi, N.; Duplay, J.; Jada, A.; Errais, E.; Ghazi, M.; Semhi, K.; Trabelsi-Ayadi, M. Removal of anionic dye from textile industries' effluents by using Tunisian clays as adsorbents. Zeta potential and streaming-induced potential measurements. Comptes Rendus Chim. 2019, 22, 113-125. [CrossRef]

44. Silva, M.P.D.; Santos, M.d.S.F.; Santos, M.R.M.C.; Santos Júnior, L.D.S.; Fonseca, M.G.D.; Silva Filho, E.C.D. Natural palygorskite as an industrial dye remover in single and binary systems. Mater. Res. 2016, 19, 1232-1240. [CrossRef]

45. Hu, Z.; Shi, F.; Liu, G.; Zhang, B.; Zhang, H. Removal of Methylene Blue from Aqueous Solution by Adsorption Onto Modified Attapulgite Clay. Energy Environ. Focus 2015, 4, 316-323. [CrossRef]

46. da Costa, F.P.; da Silva Morais, C.R.; Pinto, H.C.; Rodrigues, A.M. Microstructure and physico-mechanical properties of Al2O3doped sustainable glass-ceramic foams. Mater. Chem. Phys. 2020, 256, 123612. [CrossRef]

47. Pereira da Costa, F.; Rodrigues da Silva Morais, C.; Rodrigues, A.M. Sustainable glass-ceramic foams manufactured from waste glass bottles and bentonite. Ceram. Int. 2020, 46, 17957-17961. [CrossRef] 
48. Brunauer, S.; Emmett, P.H.; Teller, E. Adsorption of gases in multimolecular layers. J. Am. Chem. Soc. 1938, 60, 309-319. [CrossRef]

49. Lima, A.; Bruno, C.; Luna, B.; Fl, A.; Alves, S.; Lucena, S.; Margareti, S.; Meneghetti, P. From Disposal to Reuse: Production of Sustainable Fatty Acid Alkyl Esters Derived from Residual Oil Using a Biphasic Magnetic Catalyst. Sustainability 2020, $12,10159$.

50. Aljeboree, A.M.; Alshirifi, A.N.; Alkaim, A.F. Kinetics and equilibrium study for the adsorption of textile dyes on coconut shell activated carbon. Arab. J. Chem. 2017, 10, S3381-S3393. [CrossRef]

51. Kuang, Y.; Zhang, X.; Zhou, S. Adsorption of methylene blue in water onto activated carbon by surfactant modification. Water 2020, 12, 587. [CrossRef]

52. Sahu, O.; Singh, N. Significance of bioadsorption process on textile industry wastewater. In The Impact and Prospects of Green Chemistry for Textile Technology; Elsevier: Amsterdam, The Netherlands, 2019; pp. 367-416.

53. Doğan, M.; Özdemir, Y.; Alkan, M. Adsorption kinetics and mechanism of cationic methyl violet and methylene blue dyes onto sepiolite. Dye. Pigment. 2007, 75, 701-713. [CrossRef]

54. Garba, Z.N. The Relevance of Isotherm and Kinetic Models to Chlorophenols Adsorption: A Review. Avicenna J. Environ. Health Eng. 2019, 6, 55-65. [CrossRef]

55. Simonin, J.-P. On the comparison of pseudo-first order and pseudo-second order rate laws in the modeling of adsorption kinetics. Chem. Eng. J. 2016, 300, 254-263. [CrossRef]

56. Staron, P.; Chwastowski, J.; Banach, M. Sorption and desorption studies on silver ions from aqueous solution by coconut fiber. J. Clean. Prod. 2017, 149, 290-301. [CrossRef]

57. Mohammadi, N.; Khani, H.; Gupta, V.K.; Amereh, E.; Agarwal, S. Adsorption process of methyl orange dye onto mesoporous carbon material-kinetic and thermodynamic studies. J. Colloid Interface Sci. 2011, 362, 457-462. [CrossRef]

58. Suarez, M.; García-Romero, E.; Del Río, M.S.; Martinetto, P.; Dooryhee, E. The effect of the octahedral cations on the dimensions of the palygorskite cell. Clay Miner. 2007, 42, 287-297. [CrossRef]

59. Garciá-Romero, E.; Suárez, M. On the chemical composition of sepiolite and palygorskite. Clays Clay Miner. 2010, 58, 1-20. [CrossRef]

60. Suárez, M.; García-Rivas, J.; Sánchez-Migallón, J.M.; García-Romero, E. Spanish palygorskites: Geological setting, mineralogical, textural and crystal-chemical characterization. Eur. J. Mineral. 2018, 30, 733-746. [CrossRef]

61. Wang, Y.; Shen, Y.; Qin, Z.; Li, S.; Zhang, T. Preparation of three-dimensional palygorskite based carrier. MethodsX 2020, 7, 100815. [CrossRef]

62. Augsburger, M.S.; Strasser, E.; Perino, E.; Mercader, R.C.; Pedregosa, J.C. FTIR and Mössbauer investigation of a substituted palygorskite: Silicate with a channel structure. J. Phys. Chem. Solids 1998, 59, 175-180. [CrossRef]

63. Chen, H.; Zhao, Y.; Wang, A. Removal of $\mathrm{Cu}$ (II) from aqueous solution by adsorption onto acid-activated palygorskite. J. Hazard. Mater. 2007, 149, 346-354. [CrossRef]

64. Boudriche, L.; Calvet, R.; Hamdi, B.; Balard, H. Effect of acid treatment on surface properties evolution of attapulgite clay: An application of inverse gas chromatography. Colloids Surf. A Physicochem. Eng. Asp. 2011, 392, 45-54. [CrossRef]

65. Moulton, B.J.A.; Rodrigues, A.M.; Sampaio, D.V.; Silva, L.D.; Cunha, T.R.; Zanotto, E.D.; Pizani, P.S. The origin of the unusual DSC peaks of supercooled barium disilicate liquid. CrystEngComm 2019, 21, 2768-2778. [CrossRef]

66. Moulton, B.J.A.; Rodrigues, A.M.; Pizani, P.S.; Sampaio, D.V.; Zanotto, E.D. A Raman investigation of the structural evolution of supercooled liquid barium disilicate during crystallization. Int. J. Appl. Glas. Sci. 2018, 9, 510-517. [CrossRef]

67. Marosz, M.; Kowalczyk, A.; Gil, B.; Chmielarz, L. Acid-treated Clay Minerals as Catalysts for Dehydration of Methanol and Ethanol. Clays Clay Miner. 2020, 68, 23-37. [CrossRef]

68. Xavier, K.C.M.; Santos, M.D.S.F.D.; Santos, M.R.M.C.; Oliveira, M.E.R.; Carvalho, M.W.N.C.; Osajima, J.A.; Silva Filho, E.C.D. Effects of acid treatment on the clay palygorskite: XRD, surface area, morphological and chemical composition. Mater. Res. 2014, 17, 3-8. [CrossRef]

69. Oliveira, R.N.; Acchar, W.; Soares, G.D.A.; Barreto, L.S. The increase of surface area of a Brazilian palygorskite clay activated with sulfuric acid solutions using a factorial design. Mater. Res. 2013, 16, 924-928. [CrossRef]

70. Dhanya, B.A.P.; Pushpaletha, P. Metal supported and metal ion exchanged catalysts from palygorskite for acetylation reaction. Indian J. Chem. A 2020, 57, 649-654.

71. Madejova, J.; Komadel, P. Baseline studies of the clay minerals society source clays: Infrared methods. Clays Clay Miner. 2001, 49, 410-432. [CrossRef]

72. Suarez, M.; Garcia-Romero, E. FTIR spectroscopic study of palygorskite: Influence of the composition of the octahedral sheet. Appl. Clay Sci. 2006, 31, 154-163. [CrossRef]

73. Tian, G.; Wang, W.; Kang, Y.; Wang, A. Palygorskite in sodium sulphide solution via hydrothermal process for enhanced methylene blue adsorption. J. Taiwan Inst. Chem. Eng. 2016, 58, 417-423. [CrossRef]

74. Frost, R.L.; Locos, O.B.; Ruan, H.; Kloprogge, J.T. Near-infrared and mid-infrared spectroscopic study of sepiolites and palygorskites. Vib. Spectrosc. 2001, 27, 1-13. [CrossRef]

75. Frost, R.L.; Bahfenne, S.; Graham, J. Infrared and infrared emission spectroscopic study of selected magnesium carbonate minerals containing ferric iron-Implications for the geosequestration of greenhouse gases. Spectrochim. Acta Part A Mol. Biomol. Spectrosc. 2008, 71, 1610-1616. [CrossRef]

76. Liu, Q.; Yao, X.; Cheng, H.; Frost, R.L. An infrared spectroscopic comparison of four Chinese palygorskites. Spectrochim. Acta Part A Mol. Biomol. Spectrosc. 2012, 96, 784-789. [CrossRef] 
77. Rhouta, B.; Zatile, E.; Bouna, L.; Lakbita, O.; Maury, F.; Daoudi, L.; Lafont, M.C.; Amjoud, M.; Senocq, F.; Jada, A. Comprehensive physicochemical study of dioctahedral palygorskite-rich clay from Marrakech High Atlas (Morocco). Phys. Chem. Miner. 2013, 40, 411-424. [CrossRef]

78. Tian, G.; Wang, W.; Mu, B.; Kang, Y.; Wang, A. Facile fabrication of carbon/attapulgite composite for bleaching of palm oil. J. Taiwan Inst. Chem. Eng. 2015, 50, 252-258. [CrossRef]

79. Ouyang, J.; Zhao, Z.; Suib, S.L.; Yang, H. Degradation of Congo Red dye by a Fe2O3@ CeO2-ZrO2/Palygorskite composite catalyst: Synergetic effects of Fe2O3. J. Colloid Interface Sci. 2019, 539, 135-145. [CrossRef]

80. Zhang, J.; Wang, Q.; Chen, H.; Wang, A. XRF and nitrogen adsorption studies of acid-activated palygorskite. Clay Miner. 2010, 45, 145-156. [CrossRef]

81. Rusmin, R.; Sarkar, B.; Biswas, B.; Churchman, J.; Liu, Y.; Naidu, R. Structural, electrokinetic and surface properties of activated palygorskite for environmental application. Appl. Clay Sci. 2016, 134, 95-102. [CrossRef]

82. Frinisrasra, N.; Srasra, E. Effect of heating on palygorskite and acid treated palygorskite properties. Электронная обработка материалов 2008, 44, 43-49.

83. Xavier, K.C.M.; Santos, M.S.F.; Osajima, J.A.; Luz, A.B.; Fonseca, M.G.; Silva Filho, E.C. Thermally activated palygorskites as agents to clarify soybean oil. Appl. Clay Sci. 2016, 119, 338-347. [CrossRef]

84. Ogorodova, L.; Vigasina, M.; Melchakova, L.; Krupskaya, V.; Kiseleva, I. Thermochemical study of natural magnesium aluminum phyllosilicate: Palygorskite. J. Chem. Thermodyn. 2015, 89, 205-211. [CrossRef]

85. Bayram, H.; Önal, M.; Üstünışık, G.; Sarıkaya, Y. Some thermal characteristics of a mineral mixture of palygorskite, metahalloysite, magnesite and dolomite. J. Therm. Anal. Calorim. 2007, 89, 169-174. [CrossRef]

86. Amorim, K.B.; Angélica, R.S. Mineralogy and geochemistry of occurrence of palygorskite of Alcântara, S. Luís-Grajaú basin, Maranhão, Brazil. Cerâmica 2011, 57, 483-490. [CrossRef]

87. Wang, K.; Wang, L.; Zhang, Y.; Zhang, Y.; Liang, J. Microstructural evolution and sintering properties of palygorskite nanofibers. Int. J. Appl. Ceram. Technol. 2020, 17, 1833-1842. [CrossRef]

88. Bouna, L.; Rhouta, B.; Amjoud, M.; Maury, F.; Lafont, M.-C.; Jada, A.; Senocq, F.; Daoudi, L. Synthesis, characterization and photocatalytic activity of TiO2 supported natural palygorskite microfibers. Appl. Clay Sci. 2011, 52, 301-311. [CrossRef]

89. Kadï, S.; Eren, M.; Atabey, E. Dolocretes and associated palygorskite occurrences in siliciclastic red mudstones of the Sariyer formation (Middle Miocene), southeastern side of the Çanakkale strait, Turkey. Clays Clay Miner. 2010, 58, 205-219. [CrossRef]

90. Myriam, M.; Suarez, M.; Martin-Pozas, J.M. Structural and textural modifications of palygorskite and sepiolite under acid treatment. Clays Clay Miner. 1998, 46, 225-231. [CrossRef]

91. Gonzalez, F.; Pesquera, C.; Benito, I.; Mendioroz, S.; Pajares, J.A. Mechanism of acid activation of magnesic palygorskite. Clays Clay Miner. 1989, 37, 258-262. [CrossRef]

92. Omer, O.S.; Hussein, B.H.M.; Ouf, A.M.; Hussein, M.A.; Mgaidi, A. An organified mixture of illite-kaolinite for the removal of Congo red from wastewater. J. Taibah Univ. Sci. 2018, 12, 858-866. [CrossRef]

93. Wang, W.; Tian, G.; Zhang, Z.; Wang, A. A simple hydrothermal approach to modify palygorskite for high-efficient adsorption of methylene blue and $\mathrm{Cu}$ (II) ions. Chem. Eng. J. 2015, 265, 228-238. [CrossRef]

94. Dong, W.; Lu, Y.; Wang, W.; Zong, L.; Zhu, Y.; Kang, Y.; Wang, A. A new route to fabricate high-efficient porous silicate adsorbents by simultaneous inorganic-organic functionalization of low-grade palygorskite clay for removal of Congo red. Microporous Mesoporous Mater. 2019, 277, 267-276. [CrossRef]

95. Sousa, H.R.; Silva, L.S.; Sousa, P.A.A.; Sousa, R.R.M.; Fonseca, M.G.; Osajima, J.A.; Silva-Filho, E.C. Evaluation of methylene blue removal by plasma activated palygorskites. J. Mater. Res. Technol. 2019, 8, 5432-5442. [CrossRef]

96. Zhang, S.; Zhong, L.; Yang, H.; Tang, A.; Zuo, X. Magnetic carbon-coated palygorskite loaded with cobalt nanoparticles for Congo Red removal from waters. Appl. Clay Sci. 2020, 198, 105856. [CrossRef]

97. Wong, S.; Abd Ghafar, N.; Ngadi, N.; Razmi, F.A.; Inuwa, I.M.; Mat, R.; Amin, N.A.S. Effective removal of anionic textile dyes using adsorbent synthesized from coffee waste. Sci. Rep. 2020, 10, 1-13. [CrossRef]

98. Wekoye, J.N.; Wanyonyi, W.C.; Wangila, P.T.; Tonui, M.K. Kinetic and equilibrium studies of Congo red dye adsorption on cabbage waste powder. Environ. Chem. Ecotoxicol. 2020, 2, 24-31. [CrossRef]

99. Puri, C.; Sumana, G. Highly effective adsorption of crystal violet dye from contaminated water using graphene oxide intercalated montmorillonite nanocomposite. Appl. Clay Sci. 2018, 166, 102-112. [CrossRef]

100. Tang, H.; Li, W.; Zhang, T.; Li, Q.; Xing, J.; Liu, H. Improvement in diesel desulfurization capacity by equilibrium isotherms analysis. Sep. Purif. Technol. 2011, 78, 352-356. [CrossRef]

101. Litefti, K.; Freire, M.S.; Stitou, M.; González-Álvarez, J. Adsorption of an anionic dye (Congo red) from aqueous solutions by pine bark. Sci. Rep. 2019, 9, 1-11. [CrossRef]

102. Kaur, S.; Rani, S.; Mahajan, R.K. Adsorption kinetics for the removal of hazardous dye congo red by biowaste materials as adsorbents. J. Chem. 2012. [CrossRef]

103. Khan, M.A.; Uddin, M.K.; Bushra, R.; Ahmad, A.; Nabi, S.A. Synthesis and characterization of polyaniline Zr (IV) molybdophosphate for the adsorption of phenol from aqueous solution. React. Kinet. Mech. Catal. 2014, 113, 499-517. [CrossRef]

104. Zhu, Y.; Chen, T.; Liu, H.; Xu, B.; Xie, J. Kinetics and thermodynamics of Eu (III) and U (VI) adsorption onto palygorskite. J. Mol. Liq. 2016, 219, 272-278. [CrossRef] 
105. Sahu, S.; Pahi, S.; Tripathy, S.; Singh, S.K.; Behera, A.; Sahu, U.K.; Patel, R.K. Adsorption of methylene blue on chemically modified lychee seed biochar: Dynamic, equilibrium, and thermodynamic study. J. Mol. Liq. 2020, 315, 113743. [CrossRef]

106. Abdi, M.; Balagabri, M.; Karimi, H.; Hossini, H.; Rastegar, S.O. Degradation of crystal violet (CV) from aqueous solutions using ozone, peroxone, electroperoxone, and electrolysis processes: A comparison study. Appl. Water Sci. 2020, 10, 1-10. [CrossRef]

107. Cheriaa, J.; Khaireddine, M.; Rouabhia, M.; Bakhrouf, A. Removal of triphenylmethane dyes by bacterial consortium. Sci. World J. 2012. [CrossRef]

108. Jabar, J.M.; Odusote, Y.A.; Alabi, K.A.; Ahmed, I.B. Kinetics and mechanisms of congo-red dye removal from aqueous solution using activated Moringa oleifera seed coat as adsorbent. Appl. Water Sci. 2020, 10, 1-11. [CrossRef]

109. Zhang, J.; Yan, X.; Hu, M.; Hu, X.; Zhou, M. Adsorption of Congo red from aqueous solution using ZnO-modified SiO2 nanospheres with rough surfaces. J. Mol. Liq. 2018, 249, 772-778. [CrossRef]

110. El-Harby, N.F.; Ibrahim, S.M.A.; Mohamed, N.A. Adsorption of Congo red dye onto antimicrobial terephthaloyl thiourea cross-linked chitosan hydrogels. Water Sci. Technol. 2017, 76, 2719-2732. [CrossRef]

111. Zenasni, M.; Meroufel, B.; Merlin, A.; George, B. Adsorption of Congo red from aqueous solution using CTAB-kaolin from Bechar Algeria. J. Surf. Eng. Mater. Adv. Technol. 2014, 4, 332-341. [CrossRef]

112. Farias, R.S.D.; Buarque, H.L.D.B.; Cruz, M.R.D.; Cardoso, L.M.F.; Gondim, T.D.A.; Paulo, V.R.D. Adsorption of congo red dye from aqueous solution onto amino-functionalized silica gel. Eng. Sanit. e Ambient. 2018, 23, 1053-1060. [CrossRef]

113. Qin, J.; Qiu, F.; Rong, X.; Yan, J.; Zhao, H.; Yang, D. Adsorption behavior of crystal violet from aqueous solutions with chitosan-graphite oxide modified polyurethane as an adsorbent. J. Appl. Polym. Sci. 2015, 132, 41828. [CrossRef]

114. Mohanty, S.; Moulick, S.; Maji, S.K. Adsorption/photodegradation of crystal violet (basic dye) from aqueous solution by hydrothermally synthesized titanate nanotube (TNT). J. Water Process Eng. 2020, 37, 101428. [CrossRef]

115. Zhai, Q.-Z. Studies of adsorption of crystal violet from aqueous solution by nano mesocellular foam silica: Process equilibrium, kinetic, isotherm, and thermodynamic studies. Water Sci. Technol. 2020, 81, 2092-2108. [CrossRef] [PubMed]

116. Miyah, Y.; Lahrichi, A.; Idrissi, M.; Anis, K.; Kachkoul, R.; Idrissi, N.; Lairini, S.; Nenov, V.; Zerrouq, F. Removal of cationic dye "crystal violet" in aqueous solution by the local clay. J. Mater. Environ. Sci. 2017, 8, 3570-3582.

117. Hamidzadeh, S.; Torabbeigi, M.; Shahtaheri, S.J. Removal of crystal violet from water by magnetically modified activated carbon and nanomagnetic iron oxide. J. Environ. Health Sci. Eng. 2015, 13, 8. [CrossRef] 